Archive for

Organic Chemistry

Arkivoc 2018, part ii, 288-329

\title{
Alcohols in direct carbon-carbon and carbon-heteroatom bond-forming reactions: recent advances
}

\author{
Njomza Ajvazi ${ }^{a}$ and Stojan Stavber*a,b \\ `Jožef Stefan International Postgraduate School, Jamova 39, 1000 Ljubljana, Slovenia \\ ${ }^{b}$ Jožef Stefan Institute, Jamova 39, 1000 Ljubljana, Slovenia \\ Email: stojan.stavber@ijs.si
}

Dedicated to Prof. Kenneth Laali on the occasion of his $65^{\text {th }}$ birthday

Received 07-26-2017

Accepted 12-13-2017

Published on line $02-05-2018$

\begin{abstract}
In recent years, nucleophilic substitution of alcohols leading to the formation of the C-C and C-heteroatom bonds has become an attractive process used in the synthesis of organic compounds, offering a potential impact on the environment, since water is the only by-product of the reaction. A comprehensive compilation of methods for the activation and displacement of a hydroxyl group covering the last seventeen years is the objective of the present review.
\end{abstract}

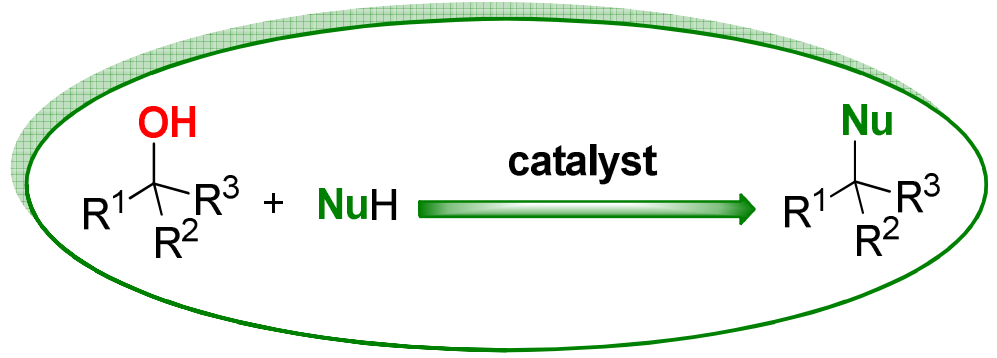

Keywords: Alcohols, C-C or C-heteroatom bond formation, nucleophilic substitution 


\section{Table of Contents}

1. Introduction

2. Catalytic Activation of Alcohols

2.1 Brønsted acid-catalyzed approaches

2.2 Metal-catalyzed approaches

2.3 Lewis/Brønsted acid combination-catalyzed approaches

3. Other Promoter-catalyzed Approaches

3.1 Molecular iodine-catalyzed approaches

3.2 HFIP and TFE-catalyzed approaches

3.3 $\mathrm{H}_{2} \mathrm{O}$-catalyzed approaches

3.4 Miscellaneous

4. Conclusions

5. Acknowledgements

References

\section{Introduction}

The development of protocols for the transformation of organic compounds following the principles of green chemistry $^{1}$ is currently one of the main trends in organic synthesis. The achievement of atom economy, efficient catalytic methodologies, suitability of a safer reaction media (water, ionic liquids, fluorous liquids, etc.) or solvent-free reaction conditions (SFRC) instead of the volatility of organic solvents, low energy consumption and low waste residues are major challenges in organic synthesis.

Hydroxyl functional group is one of the most abundant in organic compounds; thus, hydroxyl group transformations under green reaction conditions represent a considerable challenge and have attracted the interest of organic chemists.

In order to manipulate a specific transformation of a hydroxyl moiety, often its activation is necessary, but in some cases its direct substitution is also possible..$^{2-4}$ Numerous related methodologies have been elaborated using a substoichiometric amount of Brønsted acid, Lewis acid, molecular iodine or other promoter.

\section{Catalytic Activation of Alcohols}

\subsection{Brønsted acid-catalyzed approaches}

Bhanage et al. developed a new method for the synthesis of substituted alkenes, generated via a formal dimerization reaction, were obtained from secondary benzyl alcohols and styrenes using ionic liquid $\mathrm{N}$-methyl2-pyrrolidone hydrogen sulphate $[\mathrm{NMP}]^{+} \mathrm{HSO}_{4}{ }^{-}$which acts as catalyst as well as solvent. ${ }^{5}$

Later, Sanz et al. reported the benzylation of 1,3-dicarbonyl compounds catalyzed by triflic acid (TfOH, $5 \mathrm{~mol} \%)$ and $p$-toluenesulfonic acid (PTSA, 5 mol\%) using undried solvents. In the absence of catalyst, no reaction took place, while in the absence of the nucleophile, substituted alkenes were generated viaa formal dimerization reaction were obtained. ${ }^{6}$ Furthermore, an efficient 12-phosphotungstic acid (PWA) catalyzed direct substitution of benzylic and allylic alcohols with $\beta$-dicarbonyl compounds in $\mathrm{MeNO}_{2}$ or toluene has been reported. $^{7}$ 
In 2009 Funabiki's group developed the direct benzylation / allylation / propargylation of 1,3-dicarbonyl compounds catalyzed by ionic Brønsted acid a $(5 \mathrm{~mol} \%)$ with different alcohols in an ionic liquid [ $N$-ethyl- $N$ methylimidazolium trifluoromethanesulfonate (EMIOTf)]. The corresponding products were obtained in good to excellent yields (Scheme 1). Moreover, this method has been applied to tandem benzylation-cyclizationdehydration of 1,3-dicarbonyl compounds to provide functionalized $4 \mathrm{H}$-chromenes. ${ }^{8}$

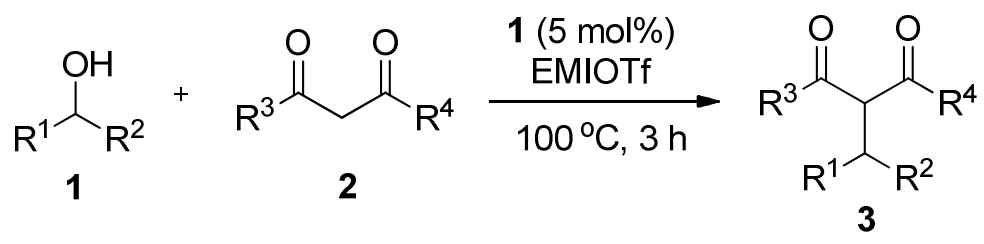

$30-98 \%$ yield

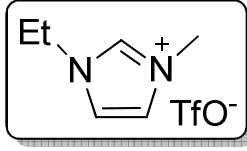

EMIOTf

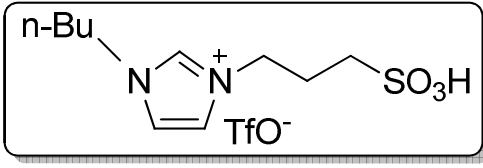

Ionic liquid catalyst a

Scheme 1. Direct benzylation/allylation/propargylation of 1,3-dicarbonyl compounds catalyzed by ionic liquid Brønsted acid a.

Recently, the synthesis of $4 \mathrm{H}$-chromenes from o-hydroxybenzylic alcohols and various diketones / ketoesters / ketoamides in the presence of sodium bisulfate on silicagel in DCE was reported ${ }^{9}$ (Scheme 2) whereas, $\mathrm{Fe}\left(\mathrm{HSO}_{4}\right)_{3}$-catalysed $C$-alkylation of a variety of $\beta$-dicarbonyl compounds (acyclic and cyclic $\beta$ diketones, $\beta$-keto esters and $\beta$-diester) using benzylic and allylic alcohols as electrophiles in 1,2-dichloroethane was developed. The catalyst can be recovered and reused up to five times. ${ }^{10}$<smiles>Oc1ccccc1C(O)c1ccccc1</smiles>

4<smiles>[R]C(=O)CC([Z7])=O</smiles>

2<smiles>[R]C(=O)C1=C([R])Oc2ccccc2C1c1ccccc1</smiles>

5

$6-98 \%$ yield

Scheme 2. Reactions of 2-(hydroxy(phenyl)methyl)phenol 4 with dicarbonyl compounds catalyzed by $\mathrm{NaHSO}_{4}-\mathrm{SiO}_{2}$.

Dodecylbenzenesulfonic acid (DBSA) has been used as surfactant-type Brønsted acid catalyst for the dehydrative nucleophile substitution of benzyl alcohols with various arenes/hetroarenes in water, whereas, common Brønsted acids such as $\mathrm{AcOH}, \mathrm{TfOH}, \mathrm{TFA}$ and TsOH were not found to be effective. Moreover, DBSA has been used for the stereoselective C-glycosylation of hydroxy sugars (Scheme 3). ${ }^{11}$ 


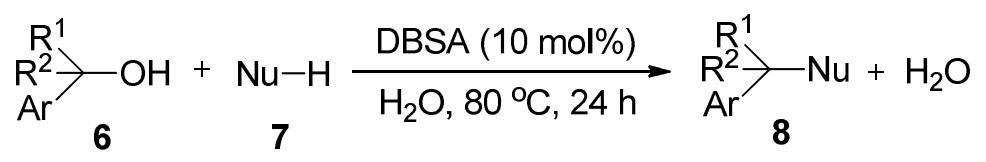

Nu: 1-methyl-1H-indole, 1,3,5-trimethoxybenzene, dibenzoylmethane etc.

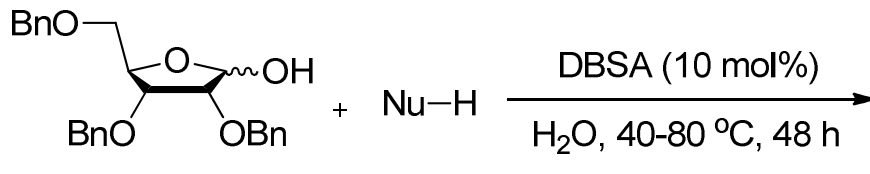

9
7<smiles>N#CC(OBr)C(COCc1ccccc1)OBr</smiles>

10

Nu: $7 a=1,2$-dimethylindole, $40^{\circ} \mathrm{C}, 61 \%$

$\mathrm{Nu}: \mathbf{7 b}=1,3,5$-trimethoxybenzene, $80^{\circ} \mathrm{C}, 62 \%$

Scheme 3. Dehydrative nucleophilic substitutions of alcohols in water catalyzed by DBSA.

In addition recent approaches for direct dehydrative coupling strategies to form $\mathrm{C}-\mathrm{C}$ bond in the presence of Brønsted acid as a catalyst have been reviewed ${ }^{29}$ and selected results are presented below in Table 1.

Table 1. Nucleophilic substitution of 1-phenylethanol 6a catalyzed by Brønsted acid

\begin{tabular}{|c|c|c|c|}
\hline $\mathrm{Ph}-\underset{\mathrm{H}}{\mathrm{H}} \mathrm{Me}$ & $+\mathrm{Me}_{\mathrm{Me}}^{\mathrm{O}}$ & \multicolumn{2}{|c|}{$\left.\right|_{\mathrm{H}} ^{\mathrm{Nu}} \mathrm{Me}$} \\
\hline Catalyst & $\begin{array}{c}\text { Reaction conditions } \\
\text { solvent/T/t }\end{array}$ & $\begin{array}{l}\text { Yield } \\
\text { (\%) }\end{array}$ & Ref. \\
\hline $\mathrm{TfOH}_{-} \mathrm{SiO}_{2}$ & $\mathrm{SFRC}$ or $\mathrm{MeNO}_{2} / 70^{\circ} \mathrm{C} / 5 \mathrm{~h}$ & 90 & 30 \\
\hline $\mathrm{HClO}_{4}$ & toluene $/ 70^{\circ} \mathrm{C} / 17 \mathrm{~h}$ & 88 & 31 \\
\hline
\end{tabular}

It is known that the use of sodium hydrogen sulfate supported on silica allows alkylation of aromatics with alcohols. After screening of various acid catalysts at $80^{\circ} \mathrm{C}, 2 \mathrm{~h}$, it was found that silica sulfuric acid (SSA) catalyzed the reaction between diphenylmethanol and benzene in $83 \%$ yield. When the reaction was performed in the presence of $\mathrm{NaHSO}_{4}$ no reaction was observed. Gel-supported acids PPA/SiO 2 and $\mathrm{SA} / \mathrm{SiO}{ }_{2}$ catalysed the reaction to some extent and the corresponding products were obtained in low yields (13-22\%); $\mathrm{ZnCl} / \mathrm{SiO}_{2}$ gave the corresponding product in $70 \%$ yield. In the cases when Lewis and $\mathrm{Br} \varnothing \mathrm{nsted}$ acids $\left(\mathrm{AlCl}_{3}\right.$, $\mathrm{FeCl}_{3}, \mathrm{H}_{2} \mathrm{SO}_{4}$ ) were used, the corresponding products were obtained in $32-76 \%$ yields. Different aromatic compounds were treated with benzhydrol catalyzed by $\mathrm{NaHSO}_{4} / \mathrm{SiO}_{2}$, in $\mathrm{DCE}$ (Scheme 4). The catalyst can be recycled and reused eight times without losing its activity. ${ }^{32}$ 
<smiles>[R]c1ccc(C(O)c2ccc([R])cc2)cc1</smiles>

6b: $\mathrm{R}=\mathrm{H}$

6c: $\mathrm{R}=\mathrm{OMe}$

6d: $\mathrm{R}=\mathrm{Cl}$ 7c<smiles>COc1cccc(OC)c1</smiles>

7

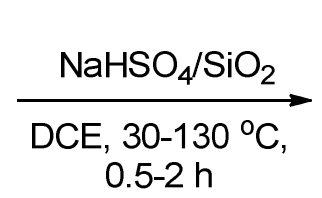

7<smiles>Oc1ccccc1</smiles>

7d<smiles>[R]c1ccc(C([N])c2ccc([R])cc2)cc1</smiles>

12

Scheme 4. Alkylation of aromatics from alcohols in the presence of $\mathrm{NaHSO}_{4} / \mathrm{SiO}_{2}$ as the catalyst.

Direct allylation of alcohols ${ }^{33,34}$ using allyltrimethylsilane for C-C bond formation as well as nucleophilic substitution of propargyl alcohols with various nucleophiles ( $\mathrm{NuH}=\mathrm{C}, \mathrm{N}, \mathrm{O}, \mathrm{S}, \mathrm{I}$ ) in the presence of Brønsted acid as catalyst have been reviewed ${ }^{35,36}$ and selected results are shown in Table $2^{35}$ and in Scheme $5^{26}$ respectively.

Table 2. Allylation of alcohols using allyltrimethysilane $\mathbf{1 3}$ catalyzed by Brønsted acid<smiles>[R]C([R2])(O)c1ccccc1</smiles>

\begin{tabular}{ccccc} 
6b and 14a & $\mathbf{1 3}$ & \multicolumn{3}{c}{15} \\
\hline Alcohol & Catalyst & $\begin{array}{c}\text { Reaction } \\
\text { conditions } \\
\text { solvent/T/t }\end{array}$ & $\begin{array}{c}\text { Yield } \\
(\%)\end{array}$ & Ref. \\
\hline $\mathbf{1 4 a}, \mathrm{R}^{1}=\mathrm{H}, \mathrm{R}^{2}=\mathrm{C} \equiv \mathrm{CPh}$ & $\mathrm{PTSA}$ & $\mathrm{MeCN} / 20-80^{\circ} \mathrm{C}$ & 73 & 33 \\
$\mathbf{6 b}, \mathrm{R}^{1}=\mathrm{H}, \mathrm{R}^{2}=\mathrm{Ph}$ & $\mathrm{PMA}$ & $\mathrm{DCM} / \mathrm{rt} / 30 \mathrm{~min}$. & 90 & 34 \\
\hline
\end{tabular}<smiles>[R]C#CC([R])([R])O</smiles>

16

$43-93 \%$ yield

Scheme 5. Direct nucleophilic substitution of propargylic alcohols catalyzed by PTSA. 
Furthermore, the Ritter reaction is a very efficient and widely used protocol for the formation of amides. Remarkable progress has been made and developments in the Ritter reaction in the presence of Brønsted acid as a catalyst were reviewed in $2012 .{ }^{42}$ In 2006, Hu et al. reported the Ritter reaction of tertiary $\alpha-\mathrm{CF}_{2} \mathrm{H}$ carbinols with acetonitrile in the presence of $98 \%$ concentrated $\mathrm{H}_{2} \mathrm{SO}_{4}$ to provide the corresponding amides in high yields. ${ }^{19}$

Earlier, in 2002, Sanz et al. reported the amidation of secondary alcohols in high yields using a Brønsted acidcatalyst (Table 3). ${ }^{43}$ The amidation of 1-phenylethanol was performed using different Brønsted acids as catalysts (10 mol\%) such as PTSA, 2,4-dinitrobenzenesulfonic acid (DNBSA), TfOH and $\mathrm{H}_{2} \mathrm{SO}_{4}$ in acetonitrile. The only difference between these acids was the reaction time required for conversion of the starting material. Due to its high activity and ease of handling, DNBSA (10 mol\%) was used as catalyst for this reaction. When the substoichiometric amount of DNBSA was decreased from 10 mol\% to 5 mol\% the reaction time was increased from $12 \mathrm{~h}$ to $24 \mathrm{~h}$ for the formation of the main product.

Table 3. Catalyst screening for the Ritter reaction of 1-phenylethanol $6 \mathbf{a}$ in acetonitrile $17 \mathbf{a}$

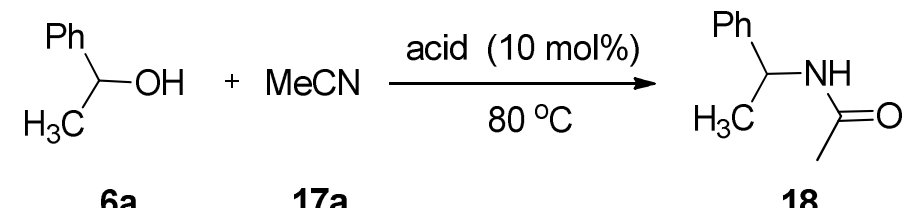

$6 \mathrm{a}$

$17 a$

18

\begin{tabular}{cccc}
\hline Acid & Amount (mol\%) & $\mathrm{t}(\mathrm{h})$ & Yield (\%) \\
\hline PTSA & 10 & 48 & 84 \\
TfOH & 10 & 12 & 85 \\
$\mathrm{H}_{2} \mathrm{SO}_{4}$ & 10 & 15 & 82 \\
DNBSA & 10 & 12 & 85 \\
DNBSA & 5 & 24 & 75 \\
\hline
\end{tabular}

Recent developments in the Ritter reaction of alcohols ${ }^{45-49}$ and nitriles catalyzed by Brønsted acids have been reviewed; ${ }^{50}$ and some of the results are shown in Table 4.

A convenient and efficient method for $\mathrm{C}-\mathrm{C}$ bond formation was developed by direct dehydrative coupling of alcohols or alkenes with alcohols using a series of alkanesulfonic acid group-functionalized ionic liquids $\left(\mathrm{SO}_{3} \mathrm{H}\right.$-functionalization IL) without additives in DCM. The protocol provides the ability for the synthesisof polysubstituted olefins in good to excellent yield. ${ }^{12}$ 
Table 4. The Ritter reaction of alcohols and nitriles catalyzed by Brønsted acid

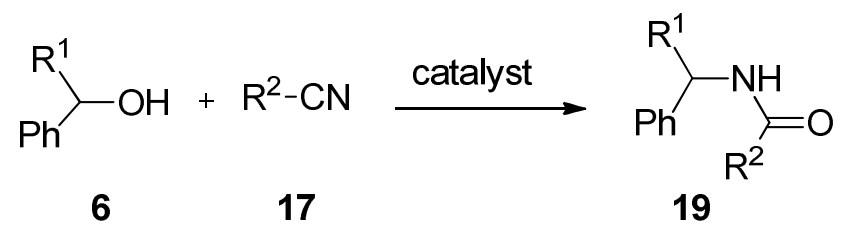

\begin{tabular}{|c|c|c|c|c|c|}
\hline Alcohol; $\mathrm{R}^{1}$ & Nitrile; $\mathrm{R}^{2}$ & Catalyst & $\begin{array}{c}\text { Reaction } \\
\text { conditions } \\
\text { solvent/T/t }\end{array}$ & $\begin{array}{c}\text { Yield } \\
(\%)\end{array}$ & Ref. \\
\hline $6 a, R^{1}=M e$ & $17 b, R^{2}=P h$ & Nanocat.-Fe- $\mathrm{OSO}_{3} \mathrm{H}$ & $\begin{array}{c}\text { SFRC } \\
90^{\circ} \mathrm{C} / 5 \mathrm{~h}\end{array}$ & 84 & 45 \\
\hline $6 b, R^{1}=P h$ & $17 a, R^{2}=M e$ & $\mathrm{CoFe}_{2} \mathrm{O}_{4} \cdot \mathrm{SiO}_{2}-\mathrm{DASA}$ & $\begin{array}{c}\text { SFRC } \\
80^{\circ} \mathrm{C} / 4 \mathrm{~h}\end{array}$ & 90 & 46 \\
\hline $6 b, R^{1}=P h$ & $17 c, \mathrm{R}^{2}=\mathrm{CH}_{2}=\mathrm{CH}-\mathrm{CH}_{2}$ & $\mathrm{NaHSO}_{4} / \mathrm{SiO}_{2}$ & $\begin{array}{c}\text { DCE } \\
80{ }^{\circ} \mathrm{C} / 8 \mathrm{~h} \\
\text { or } \mathrm{MCB} \\
30{ }^{\circ} \mathrm{C} / 0.5 \mathrm{~h}\end{array}$ & $\begin{array}{l}87 \\
\text { or } \\
84\end{array}$ & 47 \\
\hline $6 a, R^{1}=M e$ & $17 \mathrm{a}, \mathrm{R}^{2}=\mathrm{Me}$ & PFPAT & $\begin{array}{c}\text { SFRC } \\
90^{\circ} \mathrm{C} / 2 \mathrm{~h}\end{array}$ & 95 & 48 \\
\hline $6 a, R^{1}=M e$ & $17 a, R^{2}=M e$ & TfOH/SDS & $\begin{array}{c}\mathrm{H}_{2} \mathrm{O} \\
200{ }^{\circ} \mathrm{C} / 5 \mathrm{~h}\end{array}$ & 82 & 49 \\
\hline
\end{tabular}

Sanz et al. reported the direct nucleophilic substitution of the allylic and benzylic alcohols with different nucleophiles using $p$-toluenesulfonic acid monohydrate (PTSA) or polymer-bound $p$-toluenesulfonic acid (5 mol\%) where water was the only side product (Scheme 6). ${ }^{13}$
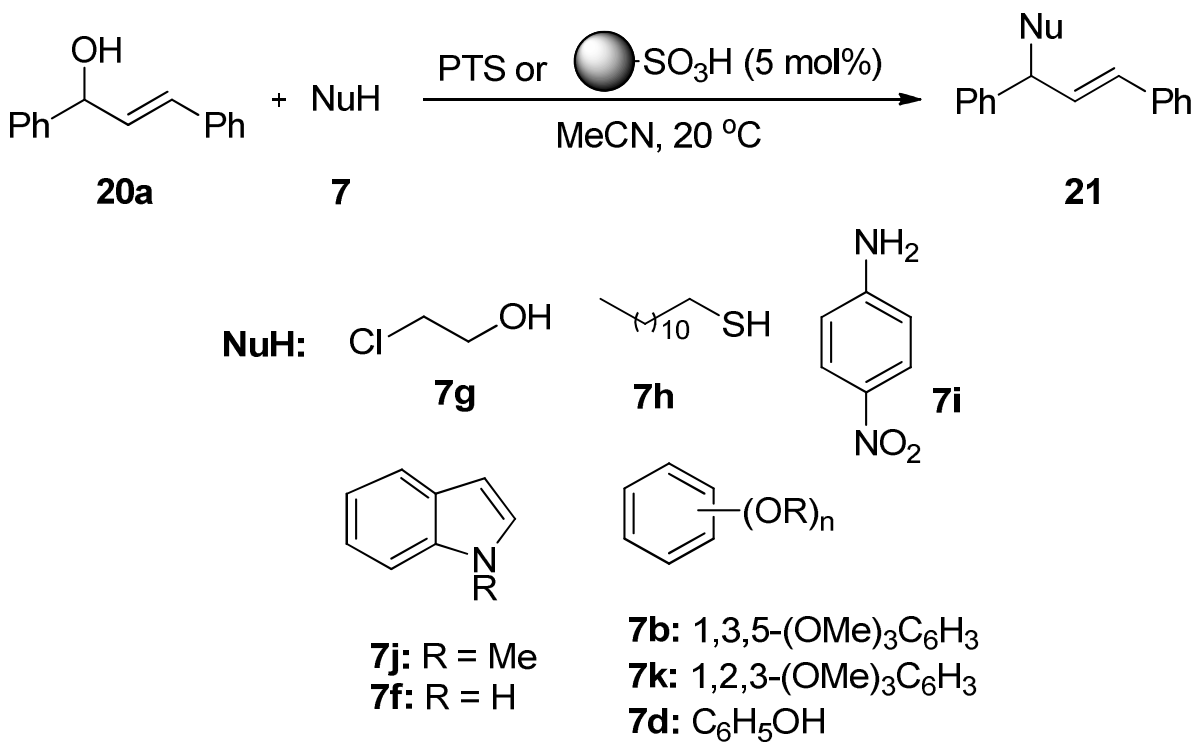

Scheme 6. Substitution reactions of alcohol with different nucleophiles catalyzed by PTSA. 
Direct nucleophilic substitutions of the propargylic alcohols with a large variety of carbon- and heteroatom-centered nucleophiles have been also reported by Sanz's group. After screening of various Brønsted acids (5 mol\%), also Lewis acids such as $\mathrm{InCl}_{3}, \mathrm{AlCl}_{3}$ and $\mathrm{CeCl}_{3}$, were shown to catalyse the reaction between an alkynol and ethanol as nucleophiles in $\mathrm{MeCN}$, at $80{ }^{\circ} \mathrm{C}$, producing the corresponding product in $>95 \%, 80 \%$ and $34 \%$ yields in 1-36 $\mathrm{h}$. The same reaction was catalysed by PTSA or CSA and the corresponding products were obtained in quantitative yields. Moreover, dilute $\mathrm{HCl}(10 \mathrm{~mol} \%)$ also catalysed this reaction in excellent yield. ${ }^{14}$

Later, Sanz's group performed a direct alkylation reaction between indoles and tertiary propargylic alcohols catalysed by $p$-toluenesulfonic acid (PTSA, 5 mol\%), in MeCN, at room temperature. ${ }^{15}$

Alkylation of furans by benzyl and propargyl alcohols ${ }^{14,16}$ in the presence of Brønsted acids as catalyst have attracted the interest of the researchers ${ }^{17}$ and selected results are shown in Table 5.

Table 5. Catalytic alkylation of furan catalyzed by Brønsted acid

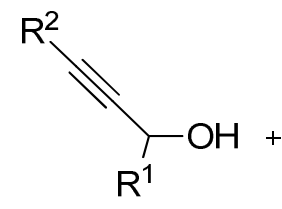

15

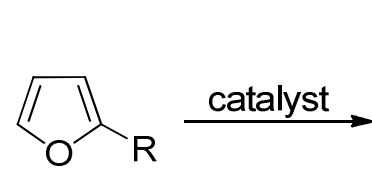

$7 e, 71$

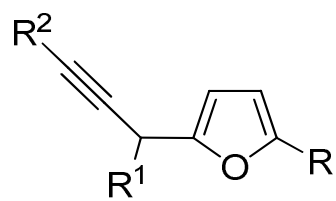

22

\begin{tabular}{ccccccc}
\hline Alcohol & & $\mathrm{R}$ & Catalyst & $\begin{array}{c}\text { Reaction conditions } \\
\text { solvent/T }\end{array}$ & Yield (\%) & Ref. \\
\hline $\begin{array}{c}\text { 14b, } \mathrm{R}^{1}=\mathbf{3}-\mathrm{MeOC}_{6} \mathrm{H}_{4}, \mathrm{R}^{2}= \\
\mathrm{Ph}\end{array}$ & 7l: & $\mathrm{H}$ & $p$ - $\mathrm{TSA}$ & $\mathrm{MeCN} / 80{ }^{\circ} \mathrm{C}$ & 76 & 14 \\
14c, $\mathrm{R}^{1}=\mathrm{R}^{2}=\mathrm{Ph}$ & 7e: & $\mathrm{Me}$ & $\mathrm{C}_{6} \mathrm{~F}_{5} \mathrm{~B}(\mathrm{OH})_{2}$ & $\mathrm{CH}_{2} \mathrm{Cl}_{2} /$ r.t. & 41 & 16 \\
\hline
\end{tabular}

Furthermore, the catalytic nucleophilic substitution of tertiary alcohols ${ }^{11,18,19}$ using carbon- or heteroatombased nucleophiles in the presence of Brønsted acid has been reviewed ${ }^{20}$ and selected results are shown in Table 6.

Table 6. Nucleophilic substitution of secondary and tertiary alcohols catalyzed by Brønsted acid

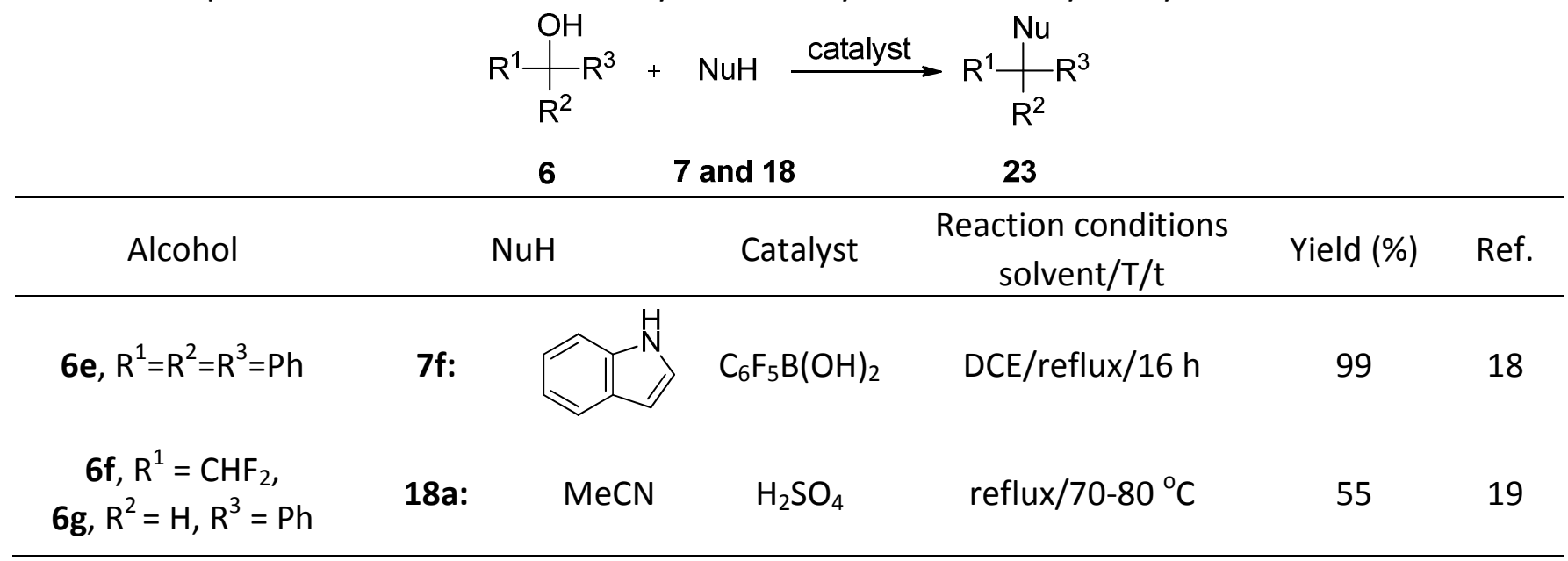


In 2013 Zheng's group developed the method for the direct nucleophilic substitution of propargylic alcohols with various nucleophiles using Amberlite IR-120H resin as the catalyst. ${ }^{21}$

The direct nucleophilic substitution of allylic alcohols ${ }^{22-24}$ through $S_{N} 1$-type reactions in the presence of Brønsted acid as a catalyst has been reviewed, ${ }^{25}$ Table 7.

Table 7. Nucleophilic substitution of allylic alcohol 20a catalyzed by Brønsted acid

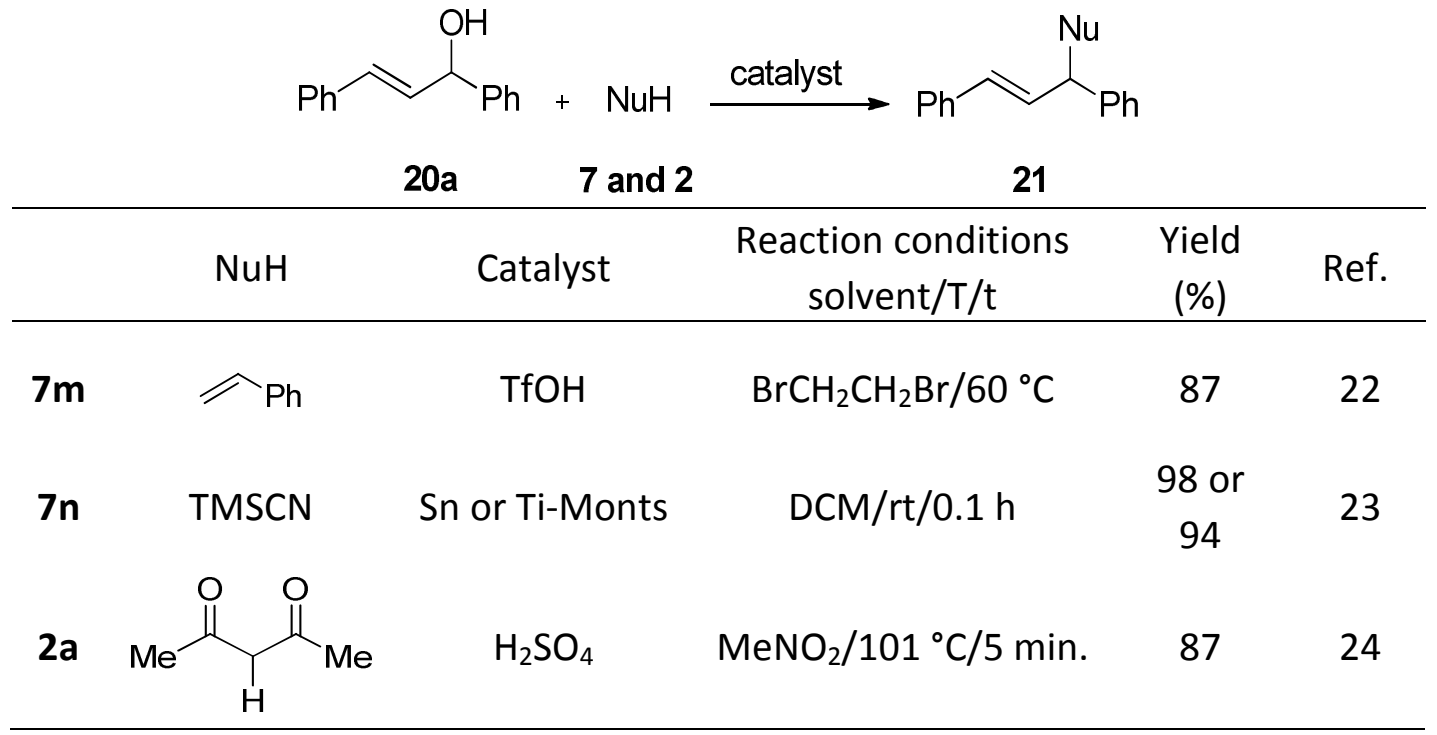

Moreover, the direct nucleophilic $S_{N} 1$-type reactions of alkynols ${ }^{26,27}$ in the presence of $B r \varnothing n s t e d$ acid as a catalyst have been reviewed ${ }^{28}$ and selected results are shown in Table 8.

Table 8. Nucleophilic substitution of alcohol 15b catalyzed by Brønsted acid

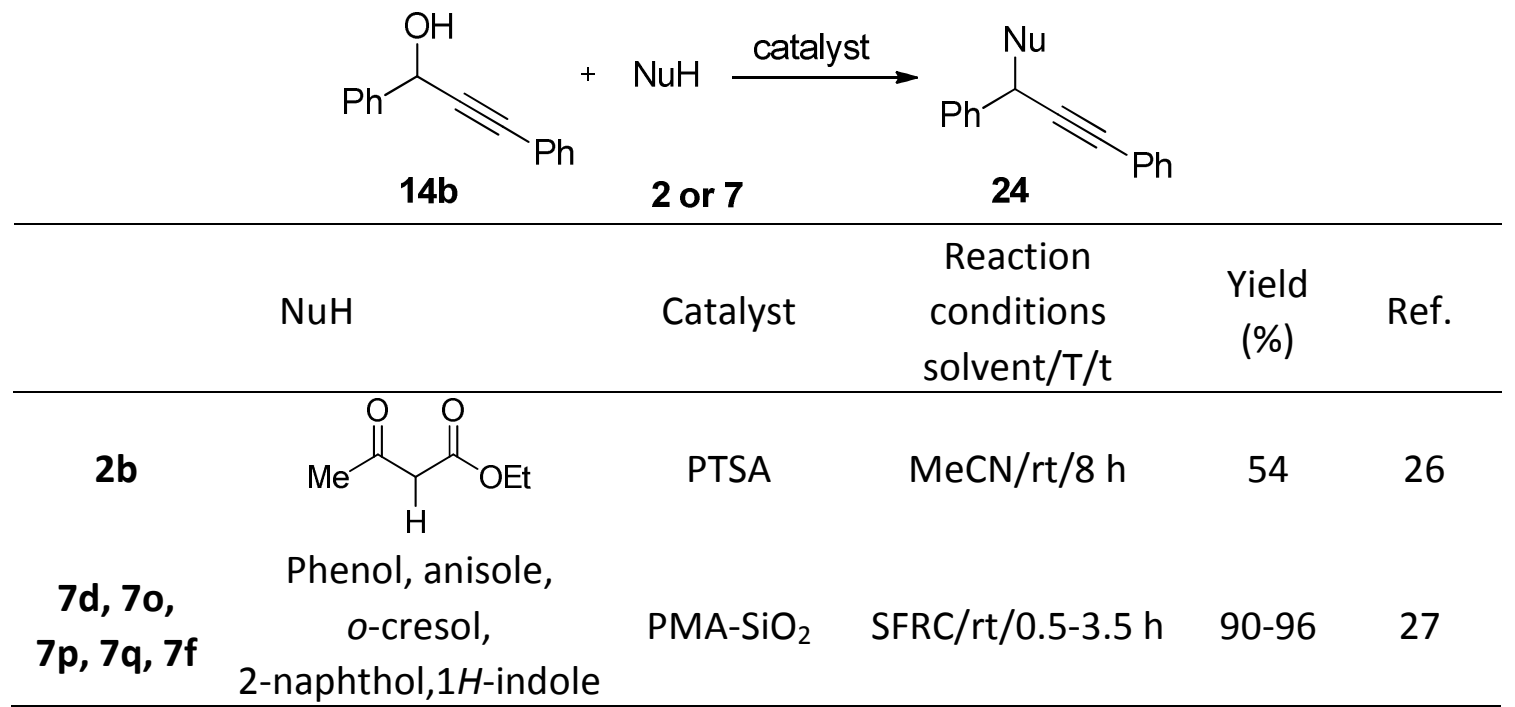

In 2016 six Brønsted acid-type amphiphilic calix[n]arene derivatives were used as catalysts in a coupling reaction of 2-methylfuran and/or $N$-methylindole with some sec-alcohols in aqueous media ${ }^{37}$ whereas, Sanz's 
group reported an efficient protocol for the synthesis of fused polycyclic indoles by intramolecular alkylation of indoles with alcohols by employing a simple Brønsted acid (PTSA) as a catalyst in MeCN. ${ }^{40}$

Interestingly, triflic acid and trimethyl orthoformate in $\mathrm{CCl}_{4}$, promoted direct $\alpha$-alkylation of unactivated ketones using benzylic alcohols as electrophiles via in situ formed acetals. ${ }^{38}$ In 2015 Bhanage et al. developed an efficient method for the synthesis of substituted aryl ketones by employing Amberlyst-15 immobilized in [Bmim] $\left[\mathrm{PF}_{6}\right]$ ionic liquid as a recyclable catalytic system which was recycled up to five times without losing the catalytic activity. ${ }^{39}$ In 2016 also, Bolshan et al. described an efficient methodology for the allylation of benzhydryl alcohols using allyltrimethylsilane in the presence of tetrafluoroboric acid $\left(\mathrm{HBF}_{4} \cdot \mathrm{OEt}_{2}\right)$ as catalyst in DCE. ${ }^{41}$

In 2011, Laali et al. reported Brønsted-acidic imidazolium ionic liquid [BMIM( $\left.\left.\mathrm{SO}_{3} \mathrm{H}\right)\right][\mathrm{OTf}]$ as a convenient and recyclable catalyst for the high yield synthesis of variety of amides under mild conditions via the Ritter reaction of alcohols with nitriles. ${ }^{44}$ Moreover, use of $\mathrm{NOPF}_{6}$ immobilized in [BMIM][PF 6 ] ionic liquid for the Ritter reaction of bromides with nitriles and for the oxidative Ritter-type synthesis of adamantyl amides from adamantane and nitriles.

Moreover, unsymmetrical ethers were prepared from different alcohols in the presence of sodium bisulfite $\left(\mathrm{NaHSO}_{3}, 0.3-1 \mathrm{~mol} \%\right)$ as the catalyst. ${ }^{51}$

In 2012 Gowda et al. performed an efficient synthesis of tert-butyl ethers from alcohols using methyl tertbutyl ethers as a tert-butyl source and solvent, in the presence of $\mathrm{H}_{2} \mathrm{SO}_{4}{ }^{52}$ Synthesis of several diphenylmethyl ethers and thioethers was achieved using a combination of microwave irradiation and protic ionic liquids (pIL), namely triethylaminomethanesulfonic acid (TeaMs) as a co-solvent and catalyst in an organic solvent (Scheme 7). ${ }^{53}$

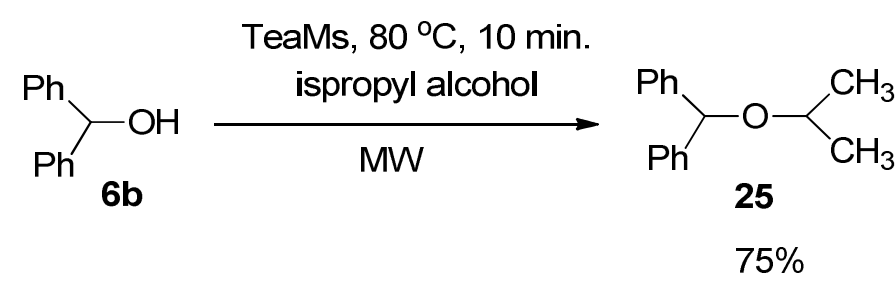

Scheme 7. Formation of diphenylmethyl ether $\mathbf{2 5}$ using protic ionic liquids.

Later, in 2015, Aoyama's group has developed a simple and efficient method for the construction of chroman ring system from a combination of benzylic and aliphatic alcohols in the presence of $\mathrm{NaHSO}_{4} / \mathrm{SiO}_{2}$ as a catalyst in DCE. ${ }^{54}$

In 2015 also phosphinic acid has been employed as catalyst for intramolecular nucleophilic substitution of the hydroxyl group of aryl, allyl, propargyl and alkyl alcohols by O-, S-, and N-centered nucleophiles to yield

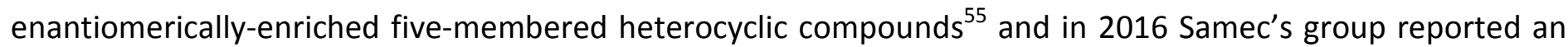
intramolecular nucleophilic substitution of stereogenic alcohols using phosphinic acid $\left(\mathrm{H}_{3} \mathrm{PO}_{2}, 10 \mathrm{~mol} \%\right)$ as a catalyst in DCE at $80^{\circ} \mathrm{C}^{56}$

\subsection{Metal-catalyzed approaches}

The major contribution in transformation of alcohols has been described by the activation of alcohols through catalytic amount of metal ions as Lewis acids. 
Ishii et al. reported the use of metal triflate (e.g. La, Yb, Sc, and $\mathrm{Hf}$ triflate) as the catalyst for reactions of benzylic alcohols with carbon (aromatic compounds, olefins, enol acetate), nitrogen (amide derivatives), and oxygen (alcohols) nucleophiles in nitromethane. $\mathrm{Hf}(\mathrm{OTf})_{4}$ was the most active catalyst for this alkylation. The catalytic activity of metal triflates and TfOH increased in the following order $\mathrm{La}(\mathrm{OTf})_{3}<\mathrm{Yb}(\mathrm{OTf})_{3}<\mathrm{TfOH}<$ $\mathrm{Sc}(\mathrm{OTf})_{3}<\mathrm{Hf}(\mathrm{OTf})_{4} \cdot{ }^{57}$

Baba and co-workers developed a direct C-C bond formation of allylic alcohols (including cyclic) and benzylic alcohols with various 1,3-dicarbonyl compounds (Scheme 8$).{ }^{58}$

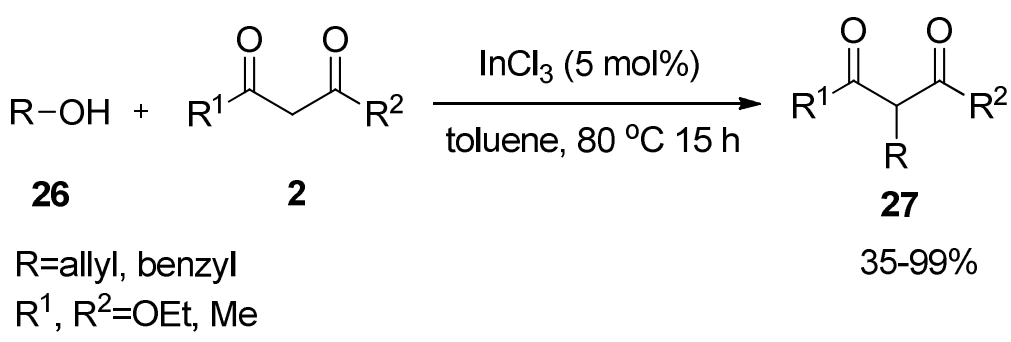

Scheme 8. $\operatorname{lnCl}_{3}$-catalyzed direct reaction of alcohols with 1,3 dicarbonyl compounds.

The reaction was studied with different metal salts catalysts $(5 \mathrm{~mol} \%)$ in toluene at $80{ }^{\circ} \mathrm{C} . \mathrm{InCl}_{3}$ was found to act as a catalyst for the reaction, as well as $\operatorname{lnBr}_{3}$. When the reaction was performed in the absence of nucleophile, dimerization took place. This was then tested with acetylacetone in the presence of water giving the corresponding alkylated product (Scheme 9). The reactions of alcohols were tested also with indoles in order to give corresponding products.

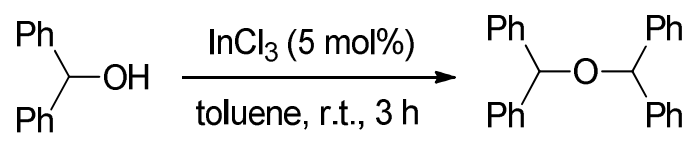

6b

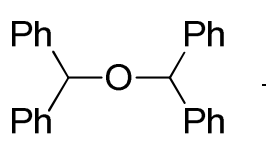

28

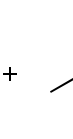

$2 a$<smiles>CC(=O)C(C(C)=O)C(c1ccccc1)c1ccccc1</smiles>

29

Scheme 9. Effect of $\mathrm{InCl}_{3}$ on dimerization and alkylation.

Chan and co-workers developed allylic alkylation of 1,3-dicarbonyl compounds with allylic alcohols including primary and terminal ones using $\mathrm{AuCl}_{3}(5 \mathrm{~mol} \%)$ with $\mathrm{AgSbF}_{6}$ (15 mol\%) as co-catalyst, in $\mathrm{MeNO}_{2}$ at room temperature. ${ }^{59}$

The direct allylation of alcohols catalyzed by the combined Lewis acid system of $\mathrm{InCl}_{3} / \mathrm{Me}_{3} \mathrm{SiBr}$ has been reported. This system was tested for the direct allylation between tertiary aliphatic trimethylsilyl ethers and allylsilanes but the yield was found to be only $34 \%$. Utilizing a combination of $\mathrm{InCl}_{3} / \mathrm{Me}_{3} \mathrm{Sil}$, which is a stronger Lewis acid, proved to be a better choice (61\% yield) at room temperature in DCM as the solvent. Furthermore, 
the use of the combination of $\mathrm{InCl}_{3}$ and $\mathrm{I}_{2}$, where $\mathrm{Me}_{3} \mathrm{Sil}$ was generated in situ from $\mathrm{I}_{2}$ and allylsilane, enhanced the yield to $76 \%$, while each of them separately did not shown any activity. ${ }^{60}$

Ishii and co-workers developed a convenient secondary benzylation and allylation of 1,3-dicarbonyl compounds in the presence of metal triflate (e.g. La, Yb, Sc, and Hf triflate, 0.5 mol\%), in $\mathrm{MeNO}_{2}$ (Scheme 10). 61

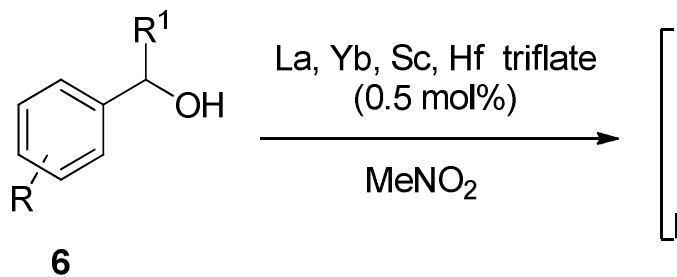

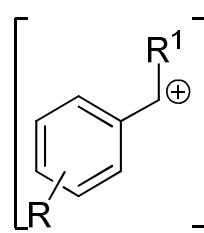

$\mathrm{R}=4-\mathrm{OMe}, 2$,6-diMe, 4-Me, 2-Me, 4-Cl, 4- $\mathrm{CO}_{2} \mathrm{Me}, 4-\mathrm{NO}_{2}$ $\mathrm{R}^{1}=$ alkyl; $\mathrm{R}^{2}=$ alkyl, aryl; $\mathrm{R}^{3}=$ alkyl, aryl, OR', NR'R"

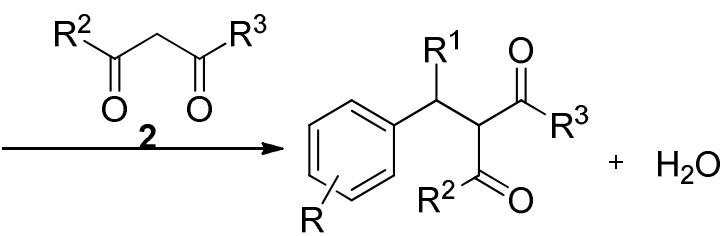

30

Scheme 10. Benzylation of 1,3-dicarbonyl compounds catalyzed by metal triflate.

Baba et al. reported a rapid and efficient microwave-irradiated protocol for $\mathrm{C}-\mathrm{C}$ coupling of a broad range of benzylic/allylic alcohols with 1,3-dicarbonyl compounds, $\beta$-keto esters, and dialkyl malonates catalyzed by transition metal salts in toluene. ${ }^{62}$ Transition-metal catalysts, salts of $\mathrm{Zn}, \mathrm{Cu}, \mathrm{Fe}, \mathrm{Sc}, \mathrm{Ru}, \mathrm{Pt}$ and Ta (3-5 mol\%) were found to provide the coupling products (Scheme 11). Among all of these catalysts copper(II) triflate (5 mol\%) has been observed to be more effective ( $98 \%$ yield) than the other catalysts, even in the case of a less reactive benzyl alcohol or diester.

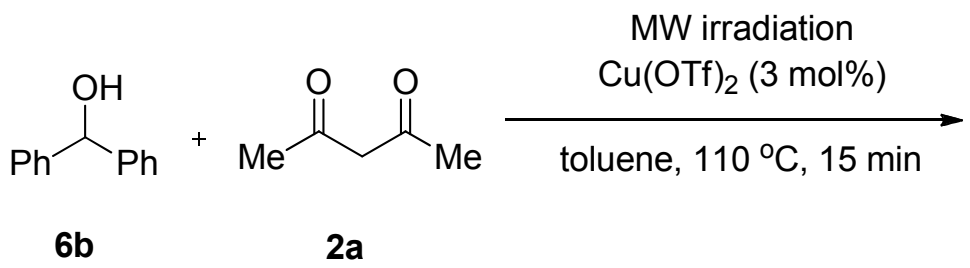<smiles>CC(=O)C(C(C)=O)C(c1ccccc1)c1ccccc1</smiles>

29

Scheme 11. MW-Irradiated reaction of diphenylmethanol (6b) with acetylacetone (2a).

Later, Fe(III) chloride catalyst was explored for the $\alpha$-substitution of Morita-Baylis-Hillman alcohols with alcohol carbon-and heteroatom-centred nucleophiles such as alcohols, arenes, 1,3-dicarbonyl compounds and thiols. $^{63}$

Tirupathi and Kim studied the role of $\mathrm{Fe}\left(\mathrm{ClO}_{4}\right)_{3} \cdot \mathrm{H}_{2} \mathrm{O}$ as catalyst for the direct $\mathrm{C}-\mathrm{C}$ bond formation of 1,3dicarbonyl compounds, electron rich arenes and heteroarenes and 4-hydroxycoumarin with secondary benzylic alcohols. ${ }^{64}$ This method was applied to the synthesis of bis-symmetrical triarylmethanes and a onestep synthesis of an anticoagulant compound, 4-hydroxy-3-(1,2,3,4-tetrahydronaphthalen-1-yl)-2H-chromen2-one (Coumatetralyl B). Dalla and Dunach's group developed the role of Sn(IV) triflimidate as the catalyst for the nucleophilic replacement of hydroxy groups of hydroxy N,O-acetals (Scheme 12) ${ }^{65}$ 


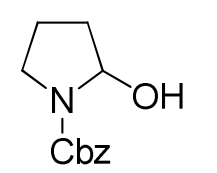

30

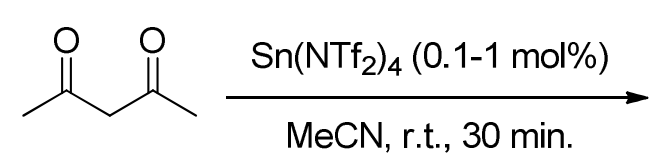

$2 a$

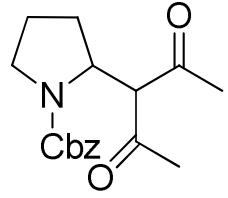

31

$75 \%$

Scheme 12. Sn(IV) triflimidate catalyzed nucleophilic substitution of hydroxy N,O-acetals.

Beller and co-workers found $\mathrm{FeCl}_{3} \cdot 6 \mathrm{H}_{2} \mathrm{O}$ to be an inexpensive catalyst for the addition of various 1,3dicarbonyl compounds with benzylic alcohols in $\mathrm{MeNO}_{2}{ }^{66}$ The protocol was useful in a one-pot synthesis of the pharmaceutical drug Phenprocoumon in 94\% yield.

Aridoss and Laali reported the condensation of propargylic alcohols with 1,3-dicarbonyl compounds in the presence of $\mathrm{Sc}(\mathrm{OTf})_{3}$ and $\mathrm{Ln}(\mathrm{OTf})_{3}$ and bismuth nitrate in imidazolium ILs. The [BMIM] $[\mathrm{PF} 6] / \mathrm{Bi}\left(\mathrm{NO}_{3}\right)_{3} \cdot 5 \mathrm{H}_{2} \mathrm{O}$ system was efficient for propargylation, vinylation, and alkylation of 4-hydroxycoumarins. ${ }^{67}$

$\mathrm{Bi}(\mathrm{OTf})_{3}(1 \mathrm{~mol} \%)$ catalyzed benzylation and allylic alkylation of 2,4-pentanediones in $\mathrm{MeNO}_{2}$ forming $\mathrm{C}$-C bond in good to excellent yields. ${ }^{68}$

$\mathrm{NbCl}_{5}$, a stable solid, was used as an efficient catalyst (5 mol\%) for C, N, O and S-nucleophilic substitution reactions of benzylic alcohols with alcohols, naphthols, indoles, resorcinols, anisole, thiols, $\mathrm{NH}_{4} \mathrm{SCN}_{\mathrm{C}}$ or $\mathrm{NaN}_{3}$ as a source of nucleophiles. Benzylic alcohols with electron withdrawing groups such as fluoro or nitro were not reactive. $^{69}$

Alkylation of indoles using allylic, benzylic and propargylic alcohols catalyzed by $\mathrm{FeCl}_{3}$ in $\mathrm{MeNO}_{2}$ were reported by Jana et al. ${ }^{70}$ Later, Jana et al. also described the addition of benzylic alcohols to terminal aryl alkynes catalyzed by $\mathrm{FeCl}_{3}$ in $\mathrm{MeNO}_{2}{ }^{71}$ In the same year, Jana et. al performed the amidation of secondary benzylic and allylic alcohols with carboxamides or $p$-toluenesulfonamide in the presence of $\mathrm{FeCl}_{3}{ }^{72}$

Yamamoto's group developed dehydrative coupling of benzylic alcohols with styrenes catalyzed by $\mathrm{Pd}(\mathrm{II})$ using $\mathrm{PPh}_{3}$ as the ligand and $\left(\mathrm{CF}_{3} \mathrm{CO}\right)_{2} \mathrm{O}$ as an additive. ${ }^{73}$

In 2011 Yi's group reported a C-C bond formation between alkenes and alcohols. The cationic ruthenium complex $\left[\left(\mathrm{C}_{6} \mathrm{H}_{6}\right)\left(\mathrm{PC}_{3}\right)(\mathrm{CO}) \mathrm{RuH}^{+} \mathrm{BF}_{4}{ }^{-}\right.$-catalyzed the alkylation in solution. ${ }^{74}$

The allylic alkylation represents an important transformation in organic chemistry and different metal processes have been described for this reaction. Direct allylation of alcohols ${ }^{75-83}$ using allyltrimethylsilane for $\mathrm{C}-\mathrm{C}$ bond formation in the presence of Lewis acid as a catalyst has attracted the interest of the researchers ${ }^{35}$ and some results are shown in Table 9. 
Table 9. Allylation of alcohols using allyltrimethysilane $\mathbf{1 3}$ catalyzed by Lewis acid

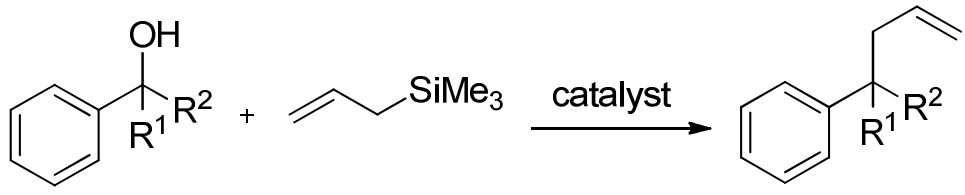

\begin{tabular}{|c|c|c|c|c|}
\hline 6,14 and 20 & 13 & 14 & & \\
\hline Alcohol & Catalyst & $\begin{array}{c}\text { Reaction } \\
\text { conditions } \\
\text { solvent/T/t }\end{array}$ & $\begin{array}{c}\text { Yield } \\
(\%)\end{array}$ & Ref. \\
\hline $6 a, R^{1}=H, R^{2}=M e$ & $\mathrm{InCl}_{3}$ & $\begin{array}{c}1,2 \mathrm{DCE} \\
80^{\circ} \mathrm{C} / 3 \mathrm{~h}\end{array}$ & 51 & 75 \\
\hline 20a, $\mathrm{R}^{1}=\mathrm{H}, \mathrm{R}^{2}=\mathrm{CH}=\mathrm{CHPh}$ & $\mathrm{Cu}\left(\mathrm{BF}_{4}\right)_{2}$ & $\begin{array}{c}\mathrm{MeCN} \\
\mathrm{rt}\end{array}$ & 86 & 76 \\
\hline $6 b, R^{1}=H, R^{2}=P h$ & $\mathrm{TiCl}_{4}$ & $\begin{array}{c}\mathrm{CH}_{2} \mathrm{Cl}_{2} \\
\mathrm{rt} / 1 \mathrm{~min} .\end{array}$ & 96 & 77 \\
\hline $6 g, R^{1}=R^{2}=M e$ & $\operatorname{lnCl}{ }_{3} / \mathrm{Me}_{3} \mathrm{SiBr}$ & $\begin{array}{c}\text { Hexane } \\
50^{\circ} \mathrm{C} / 0.5 \mathrm{~h}\end{array}$ & 75 & 78 \\
\hline $14 c, R^{1}=H, R^{2}=C \equiv C H$ & $\mathrm{FeCl}_{3}$ & $\begin{array}{l}\mathrm{MeCN} \\
\mathrm{rt} / 2 \mathrm{~h}\end{array}$ & 70 & 79 \\
\hline $14 b, R^{1}=H, R^{2}=C \equiv C P h$ & $\mathrm{BiCl}_{3}$ & $\begin{array}{c}\text { MeCN } \\
35^{\circ} \mathrm{C} / 0.5 \mathrm{~h}\end{array}$ & 89 & 80 \\
\hline 14b, $R^{1}=H, R^{2}=C \equiv C P h$ & $(\mathrm{dppm}) \mathrm{ReOCl}{ }_{3} / \mathrm{NH}_{4} \mathrm{PF}_{6}$ & $\begin{array}{c}\mathrm{MeNO}_{2} \\
65^{\circ} \mathrm{C} / 2 \mathrm{~h}\end{array}$ & 79 & 81 \\
\hline $14 b, R^{1}=H, R^{2}=C \equiv C P h$ & $\mathrm{NaAuCl}_{4} \cdot 2 \mathrm{H}_{2} \mathrm{O}$ & $\begin{array}{c}\text { DCM } \\
\text { r.t. }\end{array}$ & 97 & 82 \\
\hline $14 b, R^{1}=H, R^{2}=C \equiv C P h$ & $\mathrm{Bi}(\mathrm{OTf})_{3}$ & $\begin{array}{c}\text { (bmim) } \mathrm{BF}_{4} \\
\mathrm{rt} / 30 \mathrm{~min} .\end{array}$ & 93 & 83 \\
\hline
\end{tabular}

Heterobimetallic 'Pd-Sn' catalyst was used for the direct alkylation of arenes, heteroarenes, 1,3dicarbonyls and organosilicon nucleophiles with allylic / propargylic / benzylic alcohols in $\mathrm{MeNO}_{2}{ }^{84}$

Alkylation of electron-rich arenes using secondary and tertiary benzylic, allylic, and propargylic alcohols in the presence of calcium-based catalyst was described by Niggemann and Meel. ${ }^{85}$ Reactions were performed under the optimized conditions ( 5 mol\% $\mathrm{Ca}\left(\mathrm{NTf}_{2}\right)_{2}$ and $5 \mathrm{~mol}_{\mathrm{B}} \mathrm{Bu}_{4} \mathrm{NPF}_{6}$, in DCM, at room temperature).

A general and selective $\mathrm{C}-3$ alkylation of indoles with primary alcohols in 0 -xylene catalyzed by reusable alumina-supported $\mathrm{Pt}$ nanocluster $\left(\mathrm{Pt} / \theta-\mathrm{Al}_{2} \mathrm{O}_{3}-1.5 \mathrm{~nm}, 1 \mathrm{~mol} \%\right)$ was reported. ${ }^{86}$

Transition metals could catalyze a various transformations of allylic alcohols ${ }^{87-91}$ with various nucleophiles, Table 10. The review covers both C-C and C-heteroatom bond formation. ${ }^{92}$

Furthermore, alkylation of furans by benzyl, allyl, and propargyl alcohols ${ }^{80,93-96}$ in the presence of Lewis acids as a catalyst has been also reviewed ${ }^{17}$ and of the many results a selection is shown in Table 11. 
Table 10. Nucleophilic allylic substitution catalyzed by transition metal

\begin{tabular}{|c|c|c|c|c|c|}
\hline & & $20 \mathrm{~b}$ & 32 & & \\
\hline & $\mathrm{NuH}$ & Catalyst & $\begin{array}{c}\text { Reaction conditions } \\
\text { Solvent/T/t }\end{array}$ & $\begin{array}{c}\text { Yield } \\
(\%) \\
\end{array}$ & Ref. \\
\hline 7f: & & {$\left[\left(\eta^{3}\right.\right.$-allyl) $\mathrm{Pd}($ cod $\left.)\right] \mathrm{BF}_{4}$} & toluene $/ 50{ }^{\circ} \mathrm{C} / 20 \mathrm{~h}$ & 80 & 87 \\
\hline $7 r:$ & $\mathrm{CH}_{3} \mathrm{CH}_{2} \mathrm{OH}$ & [RuCp(o-EtOdppe)](OTs) & toluene $/ 100{ }^{\circ} \mathrm{C} / 2 \mathrm{~h}$ & 86 & 88 \\
\hline 7s: & & [RuCp(o-EtOdppe)](OTs) & toluene $/ 100{ }^{\circ} \mathrm{C} / 20 \mathrm{~h}$ & 48 & 88 \\
\hline 7d: & & {$\left[\mathrm{RuCp}\left(\mathrm{PPh}_{3}\right)_{2}\right](\mathrm{OTs})$} & toluene $/ 60^{\circ} \mathrm{C} / 3 \mathrm{~h}$ & 99 & 89 \\
\hline $7 \mathrm{t}:$ & & $\mathrm{Pt}(\mathrm{acac})_{2} / \mathrm{PPh}_{3} / \mathrm{Ti}\left(\mathrm{OPr}^{i}\right)_{4}$ & benzene/reflux/3 h & 64 & 90 \\
\hline 7u: & $\mathrm{Me}^{\prime}$ & $\mathrm{Pt}(\operatorname{cod}) \mathrm{Cl}_{2} /$ DPEphos & dioxane/reflux/6 h & 86 & 91 \\
\hline
\end{tabular}

Table 11. Catalytic alkylation of furan 7 l catalyzed by Lewis acid

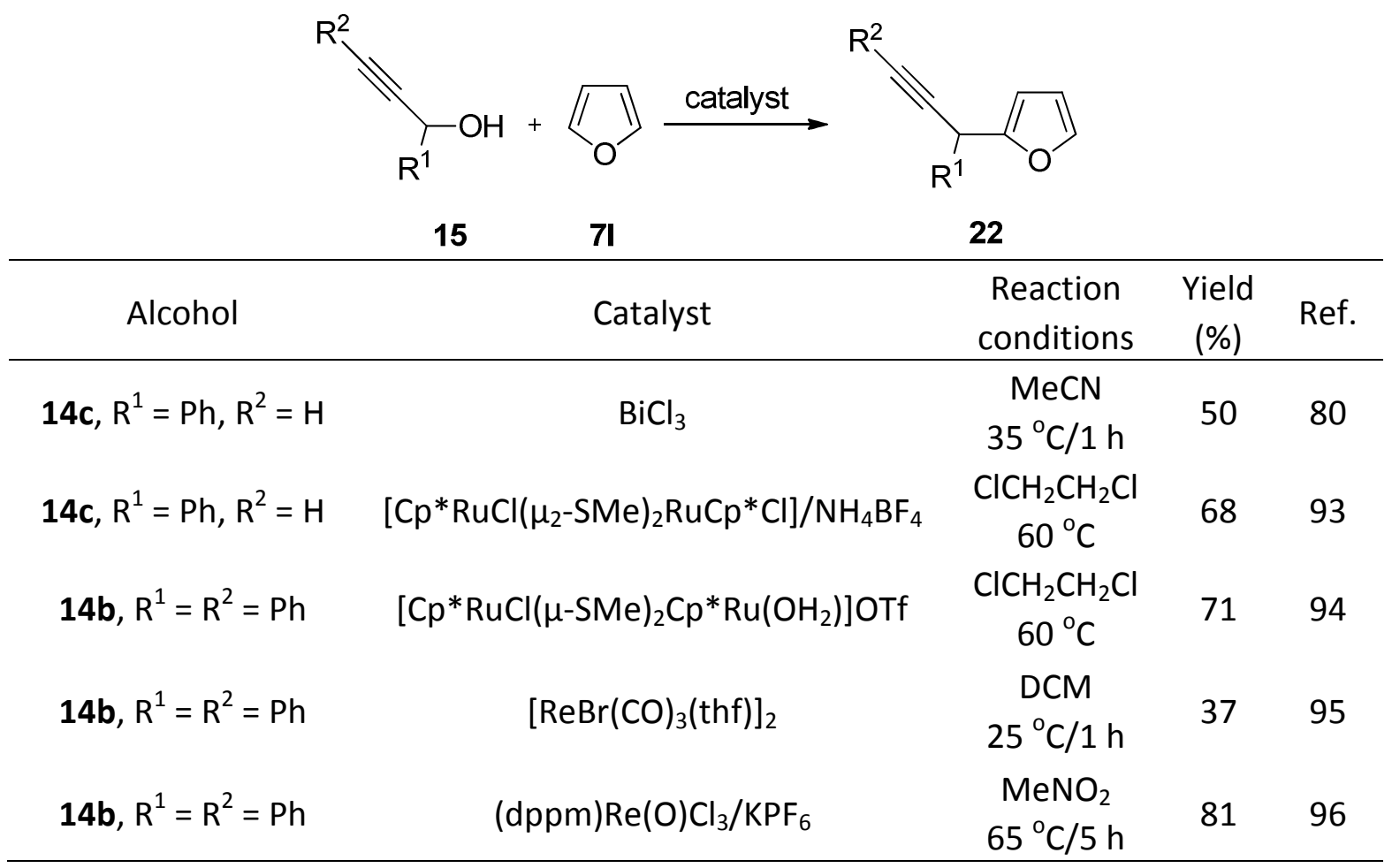

In 2013, Ramasastry et al. Reported C-C, C-N, C-O and C-S bond forming reactions of furfuryl cations with different nucleophiles catalyzed by $\mathrm{BiCl}_{3}\left(20\right.$ mol\%) in $\mathrm{MeNO}_{2}$ at room temperature. ${ }^{97}$ 
The catalytic nucleophilic substitution of tertiary alcohols of type $\mathbf{1 5}$, using carbon or heteroatom based nucleophiles in the presence of Lewis acid has been the several publications ${ }^{79,85,98,99}$ as well as a review ${ }^{20}$ and selected results are shown in Table 12.

Table 12. Nucleophilic substitution of tertiary alcohols 14 catalyzed by Lewis acid

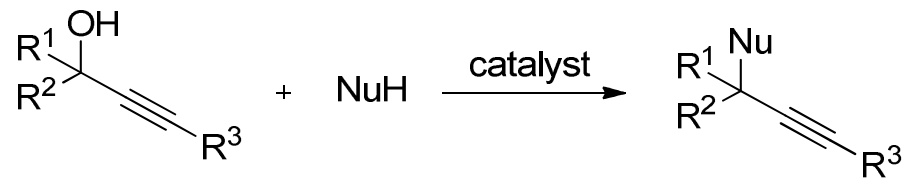

15

7

33

\begin{tabular}{|c|c|c|c|c|c|c|}
\hline Alcohol & & $\mathrm{NuH}$ & Catalyst & $\begin{array}{c}\text { Reaction } \\
\text { conditions } \\
\text { solvent/T/t }\end{array}$ & $\begin{array}{l}\text { Yield } \\
(\%)\end{array}$ & Ref. \\
\hline 14d, $R^{1}=R^{2}=M e, R^{3}=P h$ & 7r: & $\mathrm{EtOH}$ & $\mathrm{FeCl}_{3}$ & $\begin{array}{l}\mathrm{MeCN} \\
\text { r.t./12 h }\end{array}$ & 82 & 79 \\
\hline $14 d, R^{1}=R^{2}=M e, R^{3}=P h$ & 7c: & $\mathrm{OMe}$ & $\mathrm{Ca}\left(\mathrm{NTf}_{2}\right)_{2} / \mathrm{Bu}_{4} \mathrm{NPF}_{6}$ & $\begin{array}{c}\text { DCM } \\
\text { r.t. } / 2 \mathrm{~h}\end{array}$ & 87 & 85 \\
\hline $14 b, R^{1}=R^{2}=P h, R^{3}=H$ & 7v: & n-BuSH & $\begin{array}{c}{[\mathrm{Cp} * \mathrm{RuCl}(\mu-} \\
\left.\mathrm{SMe}){ }_{2} \mathrm{Cp} * \mathrm{Ru}\left(\mathrm{OH}_{2}\right)\right] \mathrm{OTf}\end{array}$ & $\begin{array}{l}\mathrm{Cl}\left(\mathrm{CH}_{2}\right)_{2} \mathrm{Cl} \\
60^{\circ} \mathrm{C} / 24 \mathrm{~h}\end{array}$ & 60 & 98 \\
\hline $14 d, R^{1}=R^{2}=M e, R^{3}=P h$ & 7g: & & $\mathrm{Al}(\mathrm{OTf})_{3}$ & $\begin{array}{c}\text { MeCN } \\
85^{\circ} \mathrm{C} / 200 \mathrm{~min} .\end{array}$ & 54 & 99 \\
\hline
\end{tabular}

The direct nucleophilic substitution of allylic alcohols ${ }^{100-103}$ as well as of tert-alcohols ${ }^{57,104,105}$ through $\mathrm{S}_{\mathrm{N}} 1-$ type reactions in the presence of Lewis acid as a catalyst have been reviewed ${ }^{25,28}$ and selected results are shown in Tables 13 and 14 respectively.

Table 13. Nucleophilic substitution of allylic alcohols $\mathbf{2 0}$ catalyzed by Lewis acid

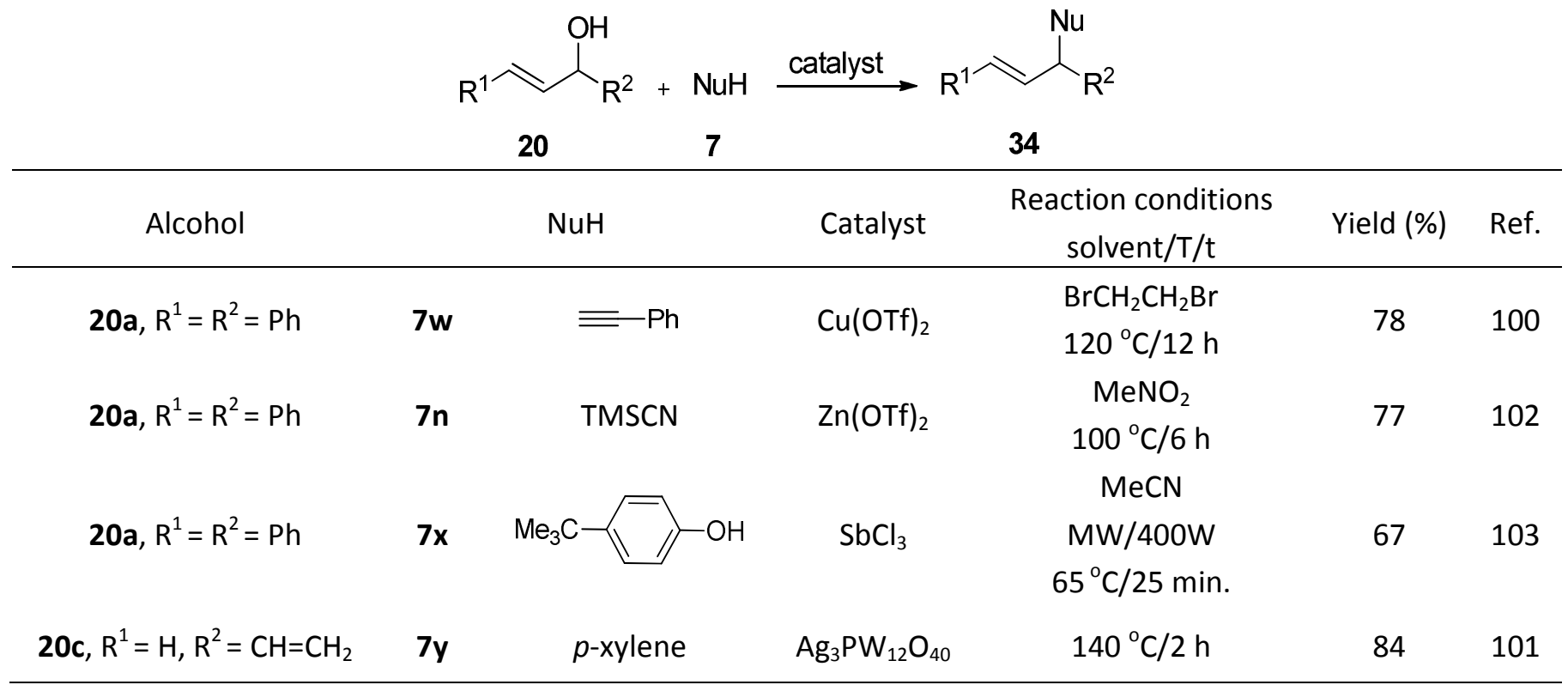


Table 14. Nucleophilic substitution of alcohols catalyzed by Lewis acid<smiles>[R]C(O)(c1ccccc1)c1ccccc1</smiles>

6 and 14 7<smiles>[R]C([R])([N])c1ccccc1</smiles>

35

\begin{tabular}{|c|c|c|c|c|c|c|}
\hline Alcohol & & $\mathrm{NuH}$ & Catalyst & $\begin{array}{c}\text { Reaction } \\
\text { conditions } \\
\text { solvent/T/t }\end{array}$ & $\begin{array}{l}\text { Yield } \\
(\%)\end{array}$ & Ref. \\
\hline $6 a, R^{1}=H, R^{2}=M e$ & 7z: & & $\mathrm{La}(\mathrm{OTf})_{3}$ & $\begin{array}{c}\mathrm{MeNO}_{2} \\
100^{\circ} \mathrm{C} / 0.25 \mathrm{~h}\end{array}$ & 99 & 57 \\
\hline $6 a, R^{1}=H, R^{2}=M e$ & 7aa: & & $\mathrm{Bi}(\mathrm{OTf})_{3}$ & $\begin{array}{c}\mathrm{DCM} \\
55^{\circ} \mathrm{C} / 8 \mathrm{~h}\end{array}$ & 58 & 104 \\
\hline $14 e, R^{1}=P h, R^{2}=C \equiv C P h$ & 7ab: & & $\mathrm{Yb}(\mathrm{OTf})_{3}$ & $\begin{array}{c}\mathrm{MeNO}_{2} \\
80^{\circ} \mathrm{C} / 24 \mathrm{~h}\end{array}$ & 90 & 105 \\
\hline
\end{tabular}

Recent approaches for direct dehydrative coupling strategies to form C-C bond in the presence of Lewis acid as a catalyst has been reviewed ${ }^{29}$ and selected results are shown in Table 15.

Table 15. Nucleophilic substitution of alcohols 6 and 20 catalyzed by Lewis acid

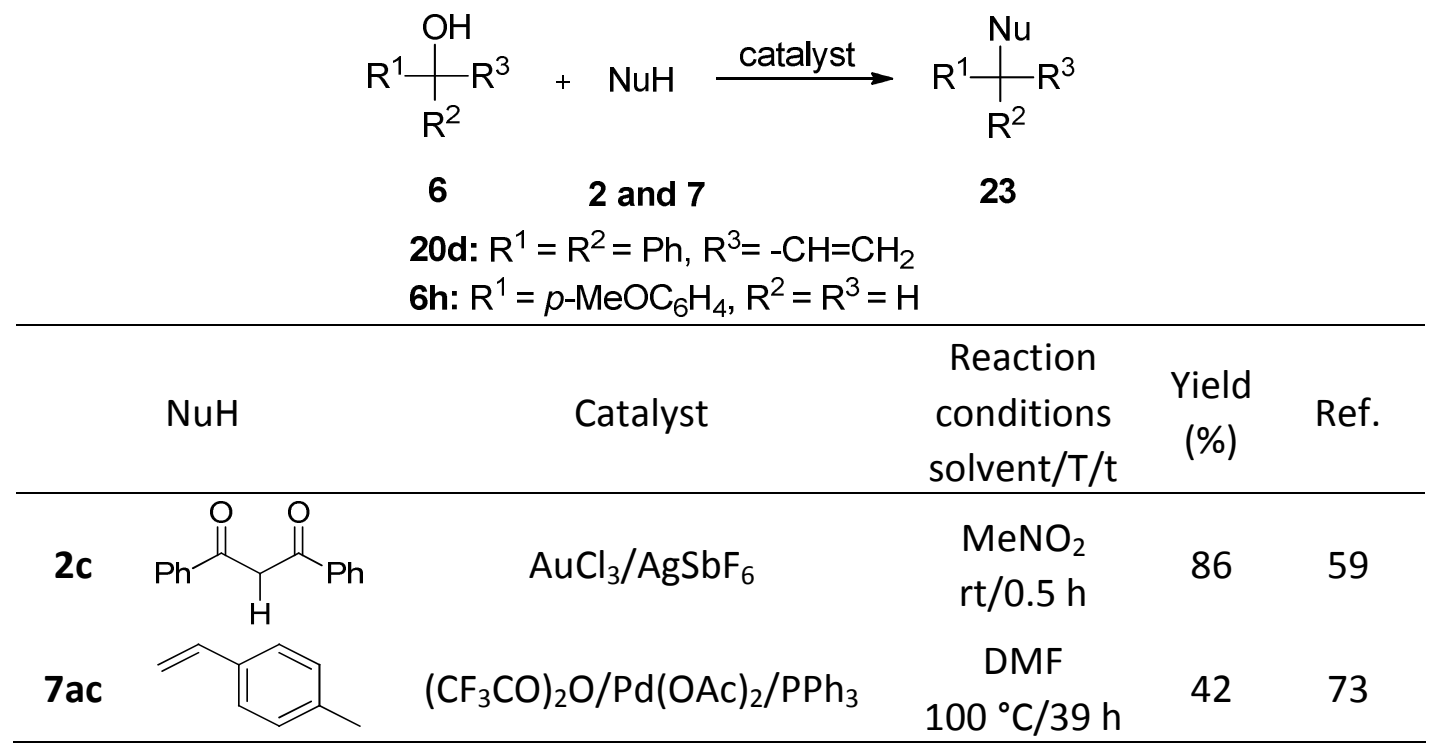

$\mathrm{Fe}\left(\mathrm{HSO}_{4}\right)_{3}$ as a reusable catalyst was used for $\mathrm{C}$-alkylation of a variety of $\beta$-dicarbonyl compounds using benzylic and allylic alcohols as electrophiles in 1,2-DCE. ${ }^{106} \mathrm{~A}$ method for the synthesis of 1,3-diarylindenes from propargylic alcohols containing aromatic ring in the presence of $\mathrm{AuBr}_{3}(5 \mathrm{~mol} \%)$ in $\mathrm{CF}_{3} \mathrm{CH}_{2} \mathrm{OH}$ under reflux was described. ${ }^{107}$ Rezgui's group developed a method for $\mathrm{C}-\mathrm{C}$ bond formation from $\beta$-dicarbonyl compounds with both cyclic and acyclic Morita-Baylis-Hillman ( $\mathrm{MBH}$ ) alcohols using $\mathrm{Et}_{3} \mathrm{~B}$ as a Lewis acid promoter in the presence of palladium catalyst. ${ }^{108}$ A new protocol for direct benzylation/allylation of malonates with alcohols via palladium catalyzed Tsuji-Trost type reactions has been described. ${ }^{109}$ 
Iron-based imidazolium salts was used as a catalysts for the synthesis of quinolines and 2- and 4allylanilines by allylic substitution of alcohols with anilines. ${ }^{110}$ Lee's group developed indium(III) chloride to gold(I) as a catalyst in dehydrative reactions with allylic alcohols. ${ }^{111}$

Protocols for the direct catalytic dehydrative substitution of alcohols recently have been reviewed ${ }^{112}$ and selected results are shown in (Table 16).

Table 16. Direct catalytic substitution of secondary benzylic alcohol 6a

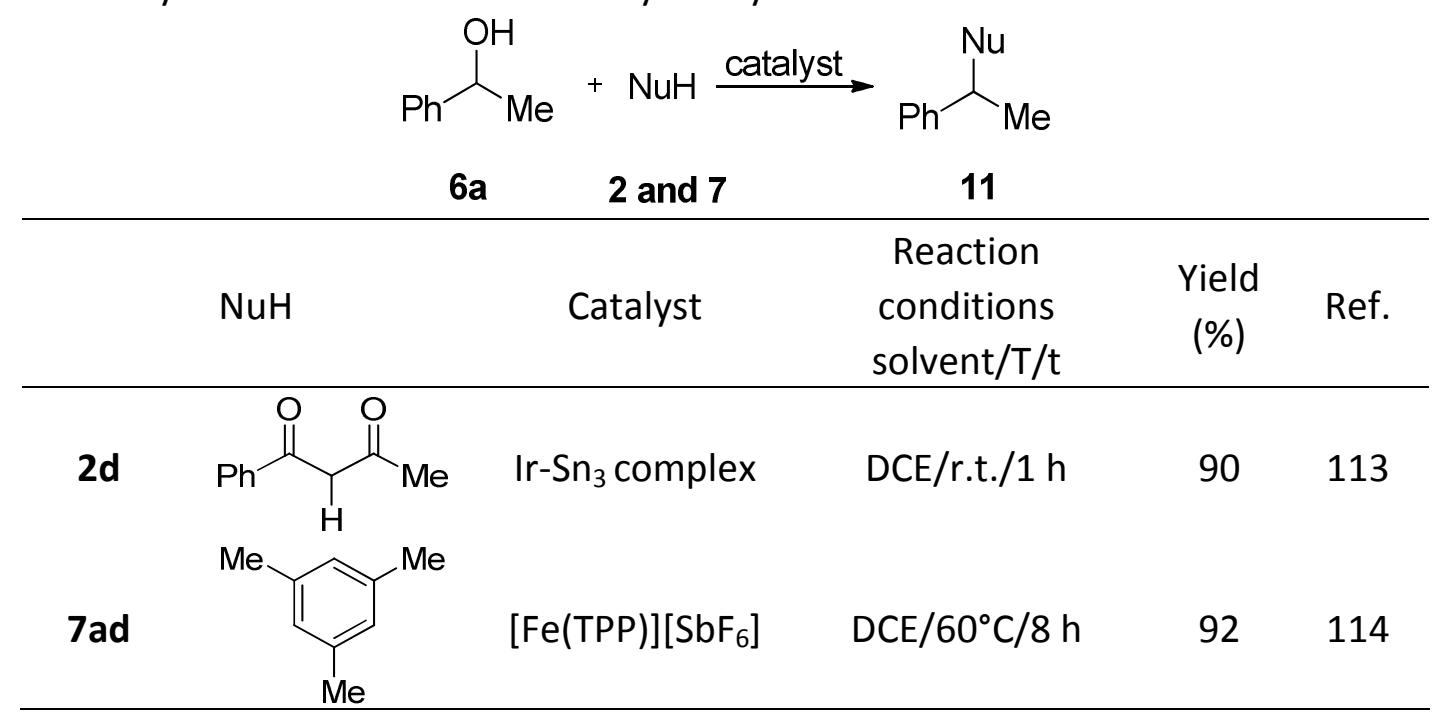

Remarkable progress has been made, and developments in the Ritter reaction in the presence of a Lewis acid catalyst were reviewed in $2012 .^{42}$ A general procedure allowing the conversion of tertiary alcohols with benzonitrile into tert-amides in the presence of $\mathrm{Bi}(\mathrm{OTf})_{3}(20 \mathrm{~mol} \%)$ as a catalyst (which was found to be the best compared with different metal triflates) in $\mathrm{H}_{2} \mathrm{O}$ at $100{ }^{\circ} \mathrm{C}$ for $17 \mathrm{~h}$ was developed by Barrett et al. ${ }^{115}$ Recent developments in Ritter reaction catalyzed by Lewis acid have been reviewed. ${ }^{50}$ The procedure for the synthesis of amides from benzohydric alcohols and nitriles in the presence of trimesitylphosphane gold (I) complex-( $\left(\mathrm{Mes}_{3} \mathrm{P}\right) \mathrm{AuCl}$ with the $\mathrm{NTf}_{2}{ }^{-}$counter anion was reported by Hashmi. ${ }^{116}$ Reactions were performed under optimized conditions ( $5 \mathrm{~mol} \%$ gold $(\mathrm{I}), 5 \mathrm{~mol} \% \mathrm{AgNTf}_{2}$ in nitrile at $75^{\circ} \mathrm{C}$ ) and the products were obtained in generally moderate yields.

Yaragorla et al. demonstrated the protocol using $\mathrm{Ca}(\mathrm{OTf})_{2}(5 \mathrm{~mol} \%)$ as a catalyst and $\mathrm{Bu}_{4} \mathrm{NPF}_{6}(5$ mol\%) as an additive for the synthesis of various amides from tertiary, secondary and benzyl alcohols and nitriles under microwave irradiation in $15 \mathrm{~min}$. in good to excellent yields. ${ }^{117}$ (Scheme 13)
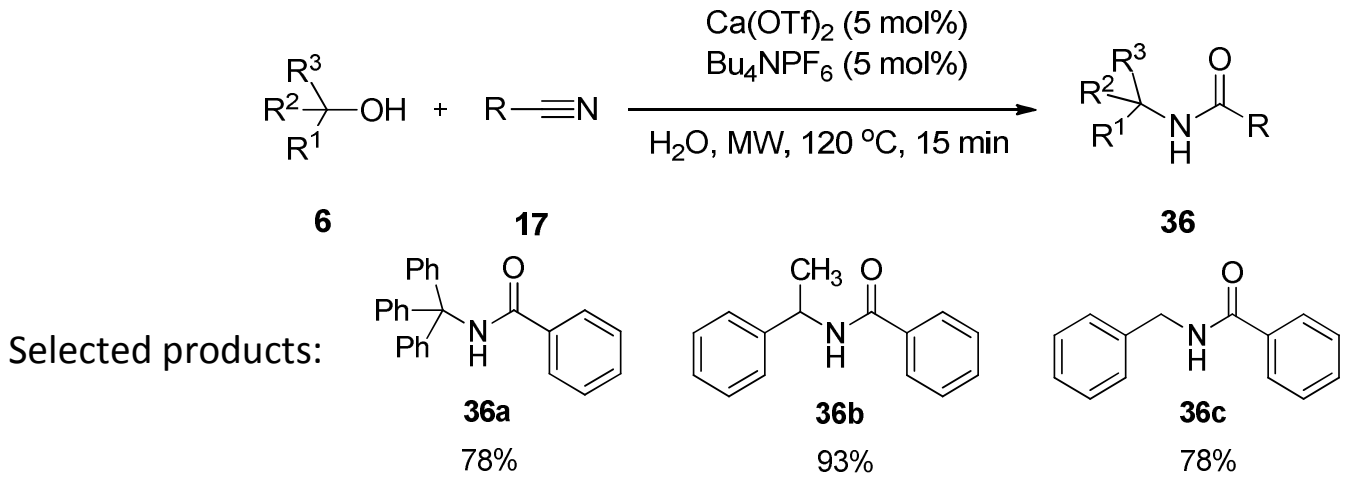

Scheme 13. $\mathrm{Ca}(\mathrm{II})$ catalyzed amidation of alcohols with nitriles. 
Wang and co-workers developed a convenient method for direct nucleophilic substitution of alcohols with aniline, amide, sulfonamide, 2,4-DNPH, and 1,3-dicarbonyl compounds catalyzed by zinc based ionic liquids [choline hydrochloride] $\left[\mathrm{ZnCl}_{2}\right]_{2}\left(1.5\right.$ equiv., $\left.100{ }^{\circ} \mathrm{C}, 1 \mathrm{~h}\right)$, which acted also as the solvent, and the obtained yields were good to excellent. ${ }^{118}$ The authors reported that the reaction worked through the carbocation mechanism, as detected by UV-VIS spectroscopy. Matute's group developed a method for alkylation of (hetero)aromate amines with various primary alcohols in the presence of ruthenium pincer complex as a catalyst. $^{119}$

The highly $\alpha$-regioselective $\operatorname{In}(\mathrm{OTf})_{3}(10 \mathrm{~mol} \%)$ catalyzed $\mathrm{N}$-nucleophilic substitution of Baylis-Hillman adducts bearing five or six-membered ring moieties with aromatic amines gave the $\alpha$-product in good yield. ${ }^{120}$ A characteristic example is shown in Scheme 14.

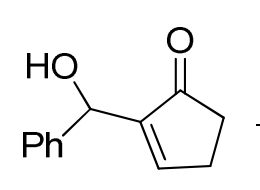

37<smiles>Nc1ccccc1</smiles>

38

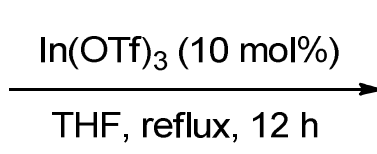

THF, reflux, $12 \mathrm{~h}$<smiles>O=C1CCC=C1C(Nc1ccccc1)c1ccccc1</smiles>

39 $63 \%$

Scheme 14. Amination of a Baylis-Hillman adduct catalyzed by $\ln (\mathrm{OTf})_{3}$.

The reaction of chromone-derived cyclic Morita-Baylis-Hillman alcohols in the presence of In(OTf) 3 as the catalyst gave 2-substituted 3-aminomethylenechromans, with rearrangement, in excellent yield (Scheme 15). ${ }^{121}$

$$
\mathrm{Ph}-\mathrm{NH}_{2}
$$

$38 \mathrm{a}$<smiles>O=c1c(C(O)c2ccccc2)coc2ccccc12</smiles>

40 $\ln (\mathrm{OTf})_{3}(10 \mathrm{~mol} \%)$

toluene, reflux, $72 \mathrm{~h}$

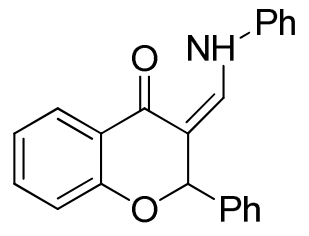

41

$99 \%$

Scheme 15. Reaction of Morita-Baylis-Hillman alcohols with amines catalyzed by $\ln (\mathrm{OTf})_{3}$.

Aluminium triflate $\mathrm{Al}(\mathrm{OTf})_{3}$ has been reported to catalyze the direct amination of allylic/propargylic/benzylic alcohols, and benzhydrols with electron-withdrawing substituents, with various nitrogen nucleophiles, in $\mathrm{MeNO}_{2}$, to achieve the corresponding biarylamines in high yield, and the dibromosubstituted product was further converted into letrozole in high yield. ${ }^{122}$

Furthermore, NiCuFeOx catalyst was designed and prepared by Shi's group for the synthesis of $N$ substituted primary, secondary, tertiary and cyclic amines (with up to 98\%) using ammonia, primary amines, or secondary amines as the nitrogen source and alcohols as the alkylation reagents. ${ }^{123}$ The authors supposed that the synergism between the $\mathrm{Ni}, \mathrm{Cu}$, and Fe species might be crucial to achieve the "borrowing-hydrogen transformation". 
In 2013 Singh et al.reported N-alkylation of aminobenzothiazoles, aminopyridines and aminopyrimidines with alcohols catalyzed by iron phthalocyanine $(1 \mathrm{~mol} \%) .{ }^{124}$ The process is also useful for the efficient synthesis of 2-substituted benzimidazoles, benzothiazoles and benzoxazole by the $\mathrm{N}$-alkylation of orthosubstituted anilines (- $\mathrm{NH}_{2},-\mathrm{SH}$, and $\left.-\mathrm{OH}\right)$ (Scheme 16).

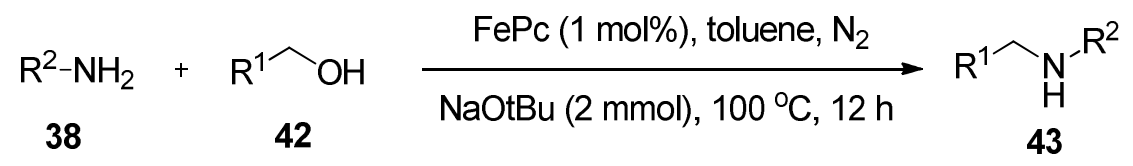

Scheme 16. N-Alkylation of various amines with alcohols.

In 2013, N-alkylation of amines and $\beta$-alkylation of secondary alcohols with primary alcohols was achieved using a mesoporous silica (SBA-15)-supported pyrimidine-substituted $\mathrm{N}$-heterocyclic carbene iridium complex as the catalyst. The catalyst could easily be recycled and re-used twelve cycles for $\mathrm{N}$-alkylation of aniline with benzyl alcohol, nine cycles for $\mathrm{N}$-alkylation of different amines with different alcohols, and eight cycles for $\beta$-alkylation of 1 phenylethanol with benzyl alcohol (Scheme 17). ${ }^{125}$

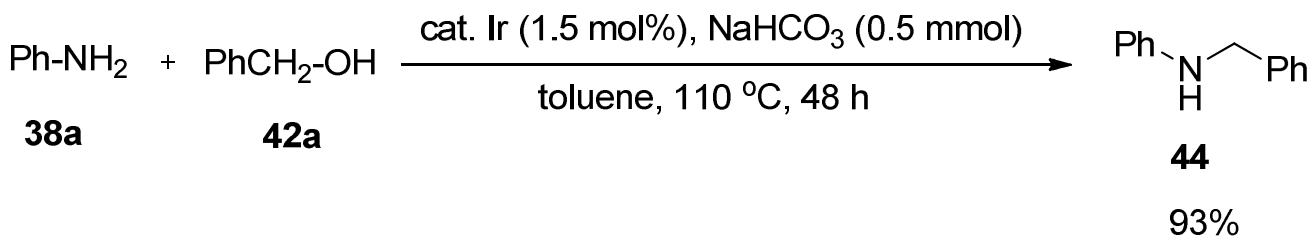

Scheme 17. N-Alkylation of aniline 38a with phenylmethanol 42a catalyzed by iridium.

Moreover, Niggemann et al. developed the method for direct amination of secondary and tertiary benzylic and allylic as well as tertiary propargylic alcohols with various nitrogen nucleophiles such as carbamates, tosylamides and anilines under the optimized conditions ( $5 \mathrm{~mol} \% \mathrm{Ca}\left(\mathrm{NTf}_{2}\right)_{2} / \mathrm{Bu}_{4} \mathrm{NPF}_{6}$, in $\mathrm{DCM}$, at r.t.). ${ }^{126}$ Amination of alcohols ${ }^{127-133}$ in the presence of Lewis acid as a catalyst has been reviewed; ${ }^{134}$ selected results are shown in Table 17. 
Table 17. Amination of primary alcohols $\mathbf{4 2}$ catalyzed by Lewis acid

\begin{tabular}{|c|c|c|c|c|}
\hline & $38 a$ & 45 & & \\
\hline Alcohol & Catalyst & $\begin{array}{c}\text { Reaction conditions } \\
\text { solvent/T/t }\end{array}$ & $\begin{array}{l}\text { Yield } \\
(\%)\end{array}$ & Ref. \\
\hline $42 a, R=H$ & {$\left[\mathrm{Cp}^{*} \mid \mathrm{ICl}_{2}\right]_{2} / \mathrm{NaHCO}_{3}$} & $\begin{array}{c}\text { Toluene } \\
110^{\circ} \mathrm{C} / 17 \mathrm{~h}\end{array}$ & 94 & 127 \\
\hline $42 a, R=H$ & {$\left[\mathrm{Ru}(\mathrm{p} \text {-cymene }) \mathrm{Cl}_{2}\right]_{2} /$ DPEphos } & $\begin{array}{c}\text { SFRC } \\
\mathrm{MW} / 115{ }^{\circ} \mathrm{C}\end{array}$ & 91 & 128 \\
\hline $42 a, R=H$ & $\mathrm{Pd} / \mathrm{Fe}_{2} \mathrm{O}_{3}$ & $160^{\circ} \mathrm{C} / 2 \mathrm{~h}$ & 90 & 129 \\
\hline $42 a, R=H$ & {$\left[\mathrm{Cp} * \operatorname{Ir}\left(\mathrm{NH}_{3}\right)_{3}\right][\mathrm{I}]_{2}$} & $\frac{\mathrm{H}_{2} \mathrm{O}}{\text { reflux/under air/6 h }}$ & 92 & 130 \\
\hline $42 b, R=4-C l$ & $\begin{array}{c}\mathrm{FeBr}_{3} / \mathrm{DL} \text {-pyroglutamic } \\
\text { acid/Cp*H }\end{array}$ & $\begin{array}{l}1,2,4-\mathrm{TMB} \\
160^{\circ} \mathrm{C} / 24 \mathrm{~h}\end{array}$ & 91 & 131 \\
\hline $42 a, R=H$ & {$[\mathrm{IrCl}(\operatorname{cod})]_{2} / \mathrm{Py}_{2} \mathrm{NPiPr}_{2}$} & $\begin{array}{c}\text { KO-t-Bu/diglyme } \\
110^{\circ} \mathrm{C} / 17 \mathrm{~h}\end{array}$ & 92 & 132 \\
\hline $42 a, R=H$ & $\mathrm{Ru}(\mathrm{OH})_{3}-\mathrm{Fe}_{3} \mathrm{O}_{4}$ & $\begin{array}{c}\mathrm{KOH} / \text { toluene } \\
130^{\circ} \mathrm{C} / 2 \mathrm{~d}\end{array}$ & 99 & 133 \\
\hline
\end{tabular}

For the amination of allylic alcohols $\mathrm{Pd}($ Xantphos $) \mathrm{Cl}_{2}$, was used as the catalyst. ${ }^{135}$

Xiong and co-workers developed a method for the direct $\mathrm{N}$-benzylation of sulfonamides with primary and secondary benzyl alcohols using boron trifluoride-diethyl ether complex $\left(\mathrm{BF}_{3} \cdot \mathrm{OEt}_{2}\right)$. A characteristic example is shown in Scheme $18 .^{136}$<smiles>[R]C(O)c1ccccc1</smiles>

6<smiles>CCOCCNS(=O)(=O)O</smiles>

46<smiles>[R]C(NS(=O)(=O)O)c1ccccc1</smiles>

47

Scheme 18. N-Benzylation of sulfonamides with benzyl alcohols.

Furthermore, Cai's group reported a new tandem catalytic process for the synthesis of substituted quinolines from primary and secondary allylic alcohols with 2-aminobenzyl alcohol using $\left[\mathrm{IrCp}^{*} \mathrm{Cl}\right]_{2} / \mathrm{KOH}$ in toluene. ${ }^{137}$ A procedure for direct dehydrative amination of benzylic and allylic alcohols catalysed by cobalt(II)/TPPMS (sodium diphenylphosphinobenzene-3-sulfonate) in water has been reported. ${ }^{138}$

Boyer et al. reported the procedure based on the utilization of $\mathrm{BiBr}_{3}$ for the benzylation of aliphatic alcohols with various benzylic alcohols under mild conditions. ${ }^{139}$ 
Yamamoto and co-workers developed a simple and efficient method for the synthesis of various allylic ethers from alcohols and alkynes using a substoichiometric amount of $\mathrm{Pd}\left(\mathrm{PPh}_{3}\right)_{4} / \mathrm{PhCO}_{2} \mathrm{H}$ in dioxane at $100{ }^{\circ} \mathrm{C}$ in good to high yields. ${ }^{140}$

Zhang et al. reported the coupling of alkynes with alcohols to give allylic ethers in the presence of palladium as a catalyst. With phenols the C-alkylation products were obtained in moderate yields (Scheme 19). ${ }^{141}$

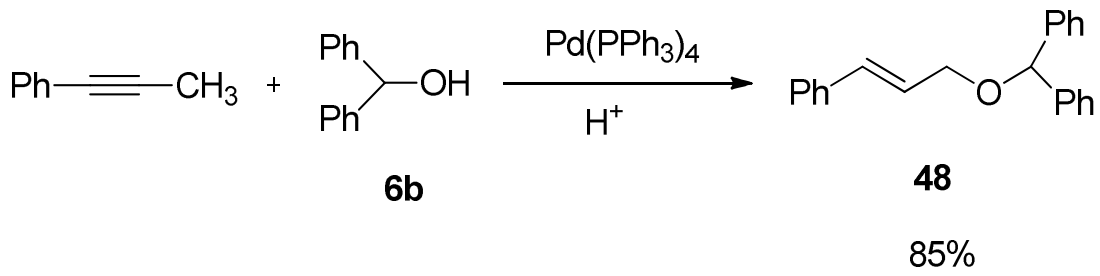

Scheme 19. Coupling of alkyne with alcohol catalyzed by $\mathrm{Pd}\left(\mathrm{PPh}_{3}\right)_{4}$.

The use of palladium complex as a catalyst for the direct preparation of symmetric and unsymmetric aromatic ethers (by coupling of two different alcohols), for the amination of secondary benzylic alcohols (with electron-deficient anilines) and for the direct formation of thioethers (by the direct action of thiols on secphenylethyl alcohol) was described by Abu-Omar. ${ }^{142}$

Ikariya et al. has shown the role of triphenyl phosphite-palladium complex as the catalyst for the substitution reactions of allylic alcohols via a direct $\mathrm{C}-\mathrm{O}$ bond cleavage to give the corresponding allylic ethers and the related $\mathrm{C}-\mathrm{C}$ and $\mathrm{C}-\mathrm{N}$ bond-forming products. ${ }^{143}$

Pale and co-workers developed a method for the protection of alcohols by the synthesis of diphenylmethyl ethers or bis(methoxyphenyl) methyl ethers catalyzed by $\mathrm{PdCl}_{2}{ }^{144}$ or $\mathrm{PdCl}_{2}\left(\mathrm{CH}_{3} \mathrm{CN}\right)_{2}{ }^{145}$ (Scheme 20).

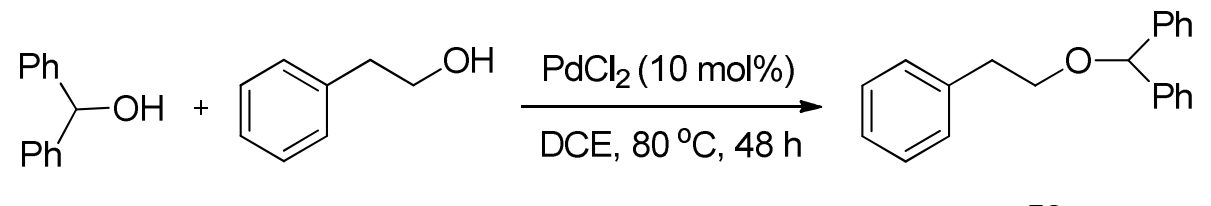

$6 b$

49

50

$87 \%$

Scheme 20. Formation of benzhydryl phenylethyl ether $\mathbf{5 0}$ in the presence of $\mathrm{PdCl}_{2}$ catalyst.

Asensio and co-workers reported the preparation of unsymmetrical ethers from alcohols using $\mathrm{NaAuCl}_{4}$ (25 mol\%) as a simple gold catalyst. ${ }^{146}$ The procedure enables the etherification of benzylic and tertiary alcohols under mild conditions in moderate to good yields.

Kerton et al. reported the procedure based on the utilization of $\mathrm{Pd}\left(\mathrm{CH}_{3} \mathrm{CN}\right)_{2} \mathrm{Cl}_{2}$ for the etherification of benzyl alcohol in hydrophobic ionic liquids (1-Butyl-3-methylimidazolium hexafluorophosphate, [BMIM]PF 6 ) using a microwave or conventional heating. ${ }^{147}$ In the presence of $\mathrm{NH}_{4} \mathrm{Cl}$ chlorination of benzyl alcohol occurred.

Palladium on magnesium oxide (Pd/MgO) catalyzed the formation of thioethers from thiols and aldehydes formed in situ from the alcohol by means of a "borrowing hydrogen" method. It was noticed that in the absence of the catalyst the reaction did not occur. ${ }^{148}$ 
Toste et al. described the role of rhenium (V)-oxo complex catalyst for the formation of C-O bond by the coupling of simple alcohols and propargyl alcohols (Scheme 21). ${ }^{149}$

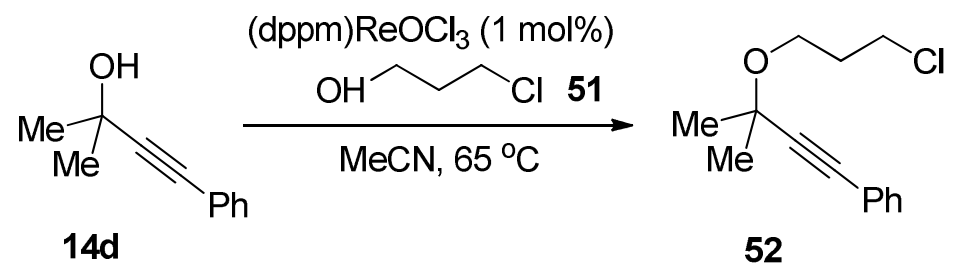

Scheme 21. Re-oxo-catalyzed etherification of 2-methyl-4-phenylbut-3-yn-2-ol 15d.

Boron trifluoride-diethyl ether catalyzed also etherification of primary and secondary alcohols. ${ }^{150}$ $\mathrm{Fe}\left(\mathrm{HSO}_{4}\right)_{3}$ catalyzed dehydration of two different alcohols to provide unsymmetrical ether under SFRC. ${ }^{151}$

An environmentally benign protocol for S-benzylation of electron-deficient benzenethiols in water using cationic Pd (II) catalysts was reported. ${ }^{152}$

The reaction of alcohols with silanes is a widely used methodology for the transformation of a hydroxyl group into an organic molecule. The introduction of TMS group into an organic molecule is achieved using hexamethyldisilazane (HMDS) in the presence of $\mathrm{LiClO}_{4}$ (solid) ${ }^{153}$ or $\mathrm{LaCl}_{3}{ }^{154}$ as catalysts.

The role of $\mathrm{InBr}_{3}$ as the catalyst was reported by Ding et al. for the direct cyanation of alcohols with TMSCN in the presence of DCM as the solvent where different benzylic alcohols could be converted to the corresponding nitriles in yields of $46-99 \%{ }^{155}$. The reaction was studied with different Lewis acids. $\mathrm{InCl}_{3}$ and $\mathrm{InBr}_{3}$ turned out to be the best catalysts. In the absence of the catalyst, no reaction was observed. The authors speculated that the catalytic cycle involved some type of carbenium intermediates which were formed by the heterolytic cleavage of C-O bond of the alcohols with the assistance of Lewis acid In(III) (and TMSCN).

Chlorination of alcohols is sometimes an important transformation in organic chemistry and it has attracted significant interest over the years. A substoichiometric amount of $\mathrm{InCl}_{3}$ in the presence of an equimolar amount of benzil, ${ }^{156}$ or a combination of $\mathrm{GaCl}_{3}(5 \mathrm{~mol} \%)$ and diethyl tartrate $(10 \mathrm{~mol} \%)^{157}$ are required for the direct chlorodehydroxylation of alcohols using $\mathrm{HSiMe}_{2} \mathrm{Cl}$ (Scheme 22).

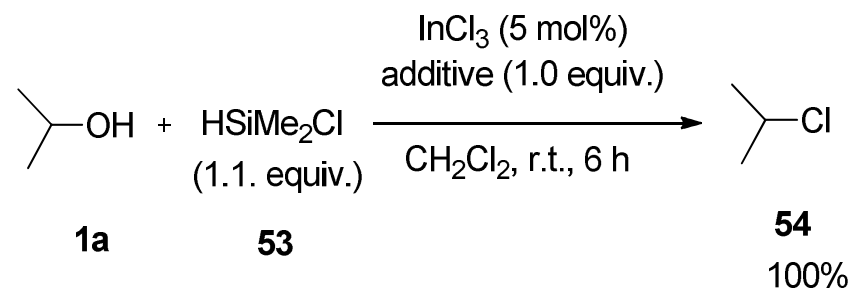

Scheme 22. Chlorination of propan-2-ol 1a catalyzed by $\mathrm{InCl}_{3}$.

The use of iron compounds as catalysts in organic synthesis has been reviewed ${ }^{158}$ and selected results are shown in Table 18. 
Table 18. Reactions of diphenylmethanol $\mathbf{6 b}$ catalyzed by iron catalyst

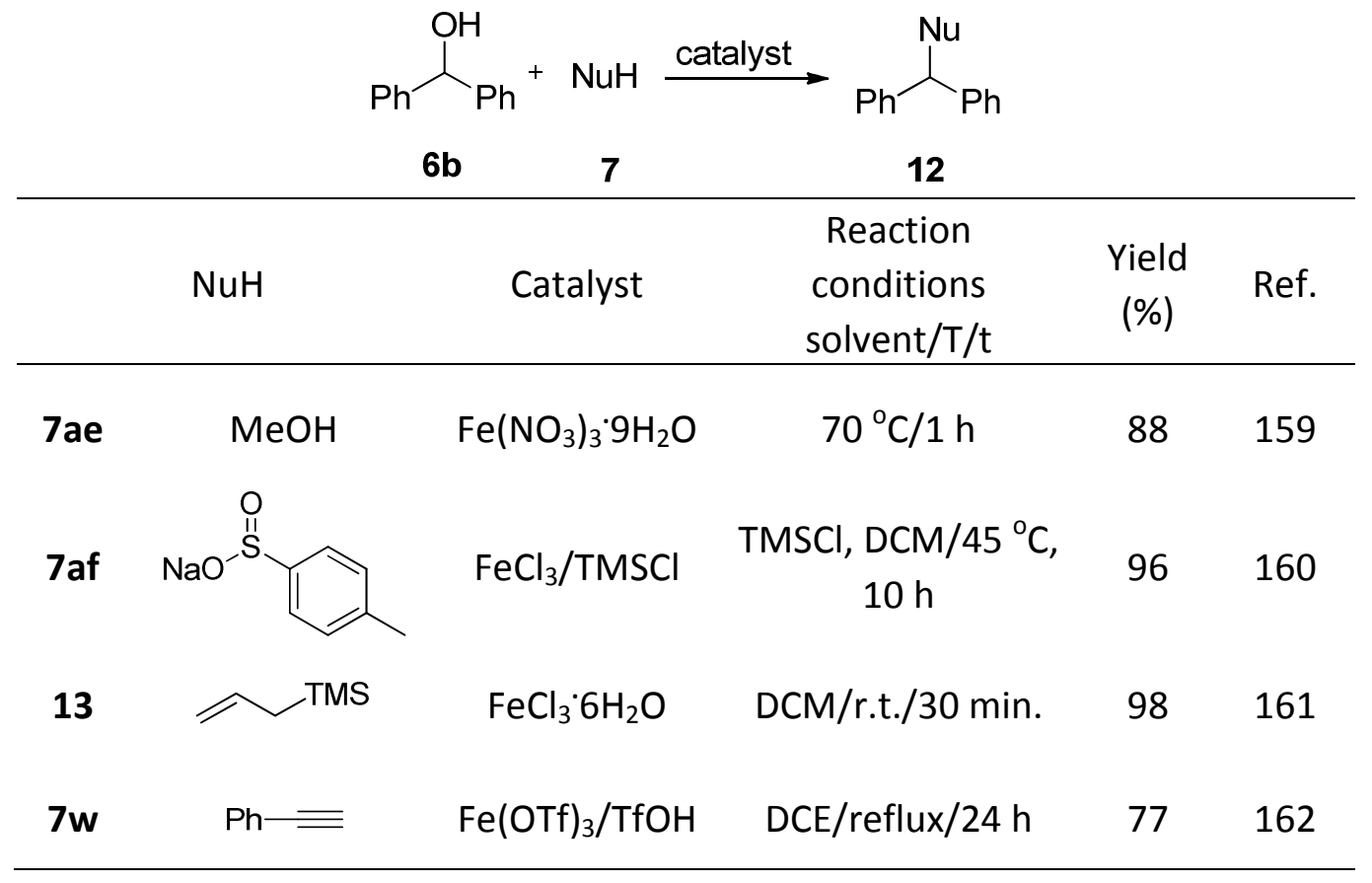

Conversion of propargylic alcohols into various valuable products using transition-metal-catalytic systems, especially those using coinage metals (i.e. copper, silver and gold) has been reviewed, ${ }^{163}$ Table 19.

Table 19. Reactions of propargylic alcohols 14 using coinage metal catalysts

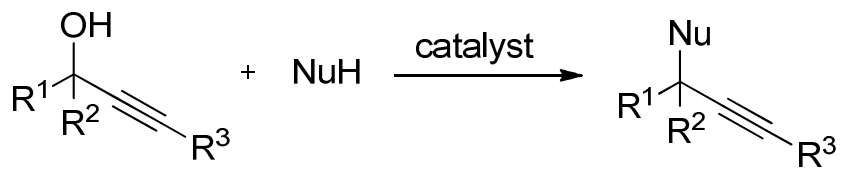

14

7 and 13

33

\begin{tabular}{|c|c|c|c|c|c|c|}
\hline Alcohol & & $\mathrm{NuH}$ & Catalyst & $\begin{array}{c}\text { Reaction } \\
\text { conditions } \\
\text { solvent/temp. }\end{array}$ & $\begin{array}{l}\text { Yield } \\
(\%)\end{array}$ & Ref. \\
\hline $\begin{aligned} \text { 14d, } R^{1} & =R^{2}=M e ; \\
R^{3} & =P h\end{aligned}$ & 13: & Allyl-TMS & $\mathrm{NaAuCl}_{4}$ & DCM/r.t. & 59 & 164 \\
\hline $\begin{array}{c}\text { 14e, } \mathrm{R}^{1}=p-\mathrm{MeOC}_{6} \mathrm{H}_{4} ; \\
\mathrm{R}^{2}=\mathrm{H} ; \mathrm{R}^{3}=\mathrm{Bu}\end{array}$ & 7ae: & $\mathrm{MeOH}$ & $\mathrm{AgNTf}_{2}$ & Toluene/r.t. & 76 & 165 \\
\hline $\begin{array}{c}14 d, R^{1}=R^{2}=M e ; \\
R^{3}=P h\end{array}$ & $7 r:$ & $\mathrm{EtOH}$ & $\mathrm{CuBr}_{2}$ & $\mathrm{MeNO}_{2} /$ r.t./10 h & 84 & 166 \\
\hline
\end{tabular}

Gold-catalyzed $\mathrm{S}_{\mathrm{N}}$ 1-type reaction of alcohols has been used to prepare unsymmetrical ethers and $\mathrm{N}$-benzyloxycarbamate(Cbz)-protected amines. ${ }^{167}$ 
Ferrocenium hexafluorophosphate $\left(\left[\mathrm{FeCp}_{2}\right] \mathrm{PF}_{6}\right)$ was used as a catalyst for the etherification of propargylic alcohols at $40{ }^{\circ} \mathrm{C}$ in DCM. ${ }^{168}$

\subsection{Lewis/Bronsted acid combination-catalyzed approaches}

Liu et al. described $\mathrm{FeCl}_{3} \cdot 6 \mathrm{H}_{2} \mathrm{O}$ catalyzed and mediated by $\mathrm{TsOH}$ direct coupling of various olefins with different types of alcohols under the typical conditions $\left(10 \mathrm{~mol} \% \mathrm{FeCl}_{3} \cdot 6 \mathrm{H}_{2} \mathrm{O}, 1.0\right.$ equiv. of TsOH, in $\mathrm{DCM}, 45$ ${ }^{\circ} \mathrm{C}$ ) providing the corresponding substituted alkene in good yields. Sterically hindered olefins such as 1-phenyl1-cyclohexene gave the coupling product in excellent yield. Since alkenes could be formed by dehydroxylation of the corresponding secondary and tertiary alcohols, the authors performed direct coupling of benzylic alcohols providing the corresponding coupling product (Scheme 23). ${ }^{169}$

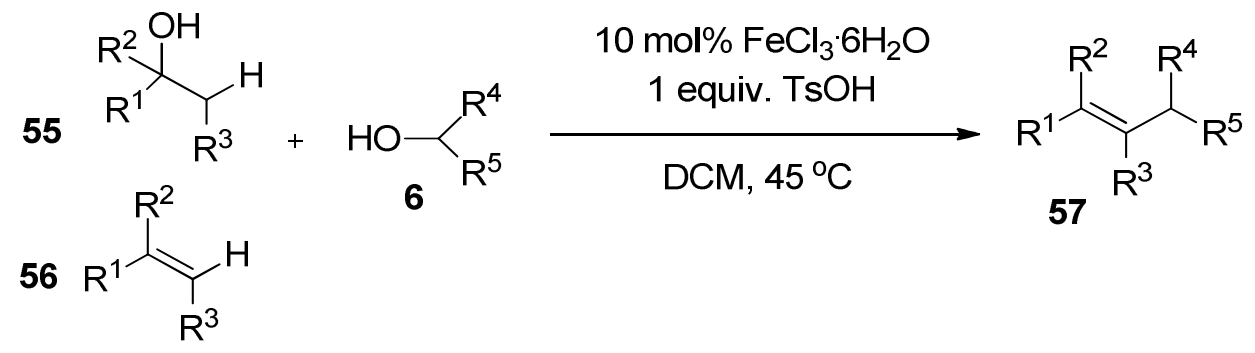

Scheme 23. Direct coupling of alcohols and alkenes with alcohols catalyzed by $\mathrm{FeCl}_{3} \cdot 6 \mathrm{H}_{2} \mathrm{O}$.

Liu's group developed addition reaction of $\beta$-diketones to secondary alcohols and styrenes to yield the $\alpha$ alkylated $\beta$-diketones catalyzed by perchlorate salt of the dicationic bipy-ruthenium complex cis-[Ru(6,6'$\mathrm{Cl}_{2}$ bipy $\left.)_{2}\left(\mathrm{H}_{2} \mathrm{O}\right)_{2}\right]^{2+}{ }^{170}$ It was proposed and confirmed by independent experiments that the catalytic addition of $\beta$-diketones to the secondary alcohols was catalyzed by the $\mathrm{Br} \varnothing$ nsted acid $\mathrm{HClO}_{4}$ generated by the reaction of the metal complex with the ß-diketone.

\section{Other Promoter-catalyzed Approaches}

\subsection{Molecular iodine-catalyzed approaches}

lodine could catalyze various transformations of alcohols, which have been reviewed ${ }^{171}$ and many results are shown in Table 20.

Benzyl $^{172-177}$, allyl ${ }^{175,178-184}$ and propargyl ${ }^{175,185,186}$ alcohols 6 were treated with various nucleophiles in the presence of $\mathrm{I}_{2}$ (2-20 mol\%) and formed different types of products (Scheme 24, Table 20). 
Table 20. Nucleophilic substitution of alcohols catalyzed by iodine

\begin{tabular}{|c|c|c|c|c|c|c|c|}
\hline $\mathrm{NuH}$ & $\begin{array}{c}\mathrm{I}_{2} \\
(\mathrm{~mol} \%)\end{array}$ & Solvent & $\mathrm{T}\left({ }^{\circ} \mathrm{C}\right)$ & $t(h)$ & Product & $\begin{array}{l}\text { Yield } \\
(\%) \\
\end{array}$ & Ref. \\
\hline & 10 & $\mathrm{CH}_{2} \mathrm{Cl}_{2}$ & $\mathrm{rt}$ & 0.25 & $23 a$ & 94 & 178 \\
\hline $\mathrm{Me}$ & 10 & $\mathrm{MeNO}_{2}$ & 80 & 1 & $23 b$ & 99 & 172 \\
\hline & 5 & $\mathrm{MeCN}$ & 0 & 0.25 & $23 c$ & 92 & 173 \\
\hline -SH & 10 & $\begin{array}{c}1,4- \\
\text { Dioxane }\end{array}$ & $\mathrm{rt}$ & 1.5 & $23 d$ & 92 & 179 \\
\hline Phenol & 5 & MeCN & -10 & 0.5 & $23 e$ & 90 & 185 \\
\hline & 5 & $\mathrm{CH}_{2} \mathrm{Cl}_{2}$ & $\mathrm{rt}$ & 1.5 & $23 f$ & 90 & $\begin{array}{l}180, \\
181\end{array}$ \\
\hline $\mathrm{Ph}=\mathrm{TMS}$ & 10 & $\mathrm{CH}_{2} \mathrm{Cl}_{2}$ & 0 & 3 & $23 g$ & 96 & 186 \\
\hline $\mathrm{Me}-\longrightarrow \mathrm{S}_{\mathrm{N}}^{\mathrm{O}}-\mathrm{N}^{\prime}$ & 5 & $\mathrm{CH}_{2} \mathrm{Cl}_{2}$ & $\mathrm{rt}$ & $3^{a}$ & $23 \mathrm{~h}$ & 85 & $\begin{array}{l}182 \\
183\end{array}$ \\
\hline $\mathrm{PhCONH}_{2}$ & 2 & $\mathrm{MeCN}$ & Reflux & 2 & $23 \mathbf{i}$ & 98 & 175 \\
\hline Anisole & 10 & SFRC & 60 & $4^{b}$ & $23 \mathbf{j}$ & 88 & 174 \\
\hline $\mathrm{MeCN} / \mathrm{H}_{2} \mathrm{O}$ & 20 & PhMe & 110 & $4^{c}$ & $23 k$ & 85 & 176 \\
\hline $\mathrm{Me}_{\mathrm{O}}$ & 10 & $\mathrm{MeNO}_{2}$ & 80 & / & 231 & 78 & 172 \\
\hline
\end{tabular}

Primary and secondary benzylic alcohols supplied ethers, such as $58\left(R^{1}=R^{2}=H, R^{3}=P h\right)$, under SFRC. ${ }^{187}$

Tertiary alcohols underwent elimination of water in the absence of nucleophiles providing the corresponding alkenes such as $59\left(R^{1}=R^{2}=R^{4}=H\right)$, in high yields (Scheme 24). ${ }^{187}$

Liu et al. described C-C and C-N bonds formation from allylic/propargylic and other alcohols with various $\mathrm{C}$ - and $\mathrm{N}$-nucleophiles in the presence of iodine catalyst (10 mol\%) in $\mathrm{MeCN}$, at room temperature. ${ }^{188}$

Jereb reported an environmentally friendly synthesis of trimethylsilyl ethers from alcohols, phenols and carbohydrates in the presence of HMDS under solvent-free conditions, at room temperature. Sterically hindered phenols, carbohydrates and most of the alcohols required a substoichiometric amount of iodine (up to 2 mol\%). ${ }^{189}$

Das et al. reported one-spot synthesis of pentasubstituted pyrroles by the tandem reaction of amines, dialkyl acetylenedicarboxylates, and propargylic alcohols catalyzed by iodine (10 mol\%), in toluene and the obtained corresponding products were in high yields (75-88\%). ${ }^{190}$ 


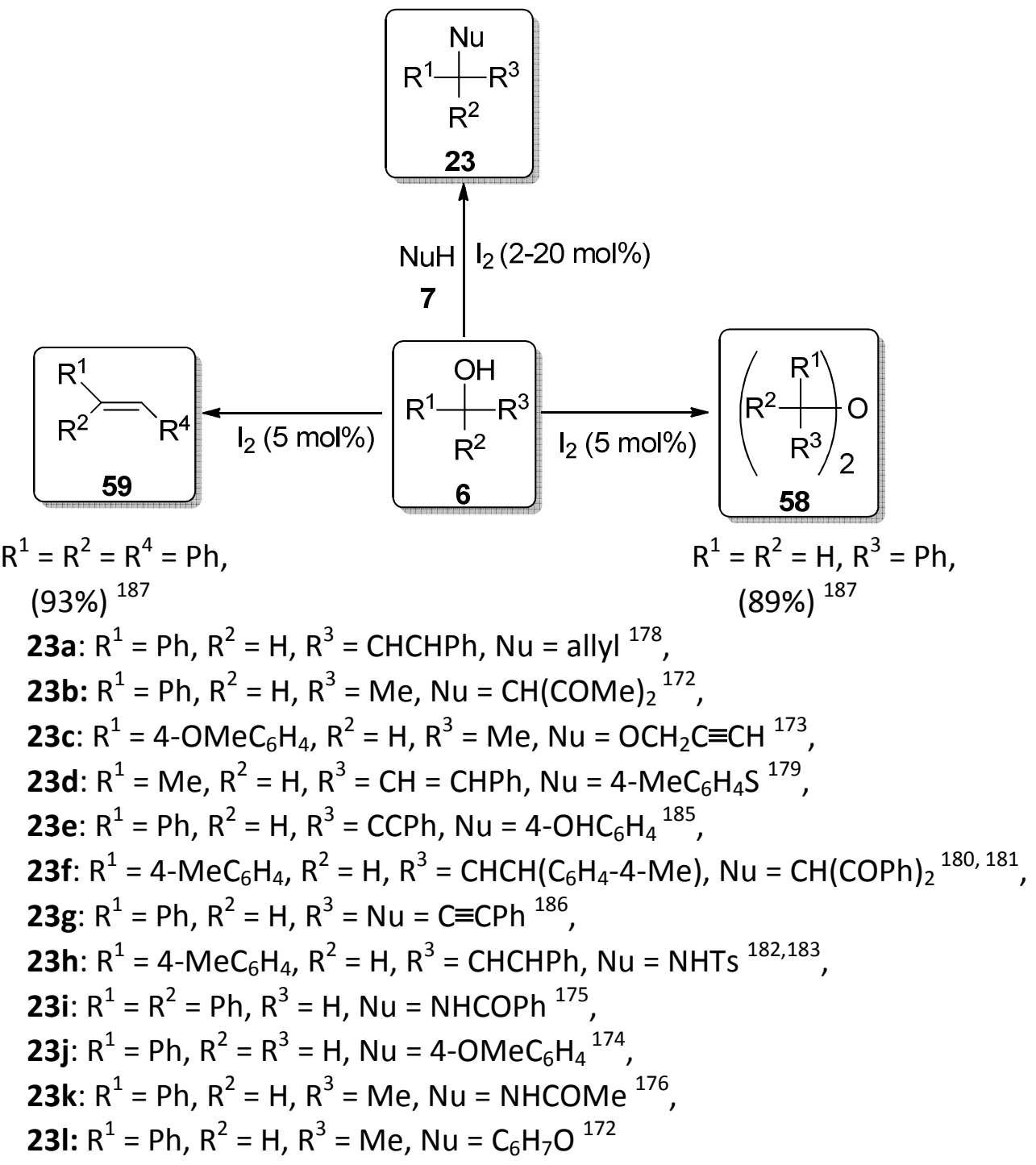

Scheme 24. Substitution, dimerization or elimination of alcohols catalyzed by iodine.

\subsection{HFIP and TFE-catalyzed approaches}

In 2012, Najera and co-workers investigated the fluorinated alcohols, such as 1,1,1,3,3,3-hexafluoroisopropanol (HFIP) and 2,2,2-trifluoroethanol (TFE), used as solvents and promoted direct substitution reaction of allylic alcohols with nitrogen, silyl, and carbon nucleophiles (Scheme 25). The reactions were performed at room temperature up to $70{ }^{\circ} \mathrm{C}$ and afforded allylic substitution product in high yields, especially when HFIP was employed as the solvent. ${ }^{191}$

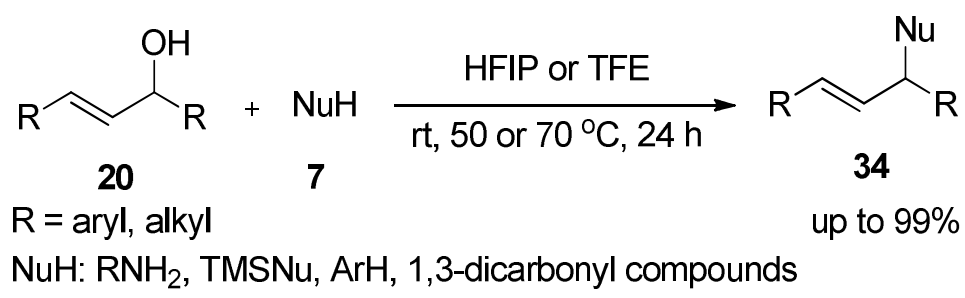

Scheme 25. Direct allylic substitution of alcohols promoted by fluorinated alcohols. 


\section{3 $\mathrm{H}_{2} \mathrm{O}$-catalyzed approaches}

Cozzi and Zoli performed the direct nucleophilic substitution of alcohol "on water" without the addition of any Brønsted/Lewis acid (Scheme 26). ${ }^{192}$ Reactions depend on the stability of the corresponding carbocation. The reactions were performed in deionized water at $80{ }^{\circ} \mathrm{C}$. Various nucleophiles reacted smoothly with the selected alcohols.

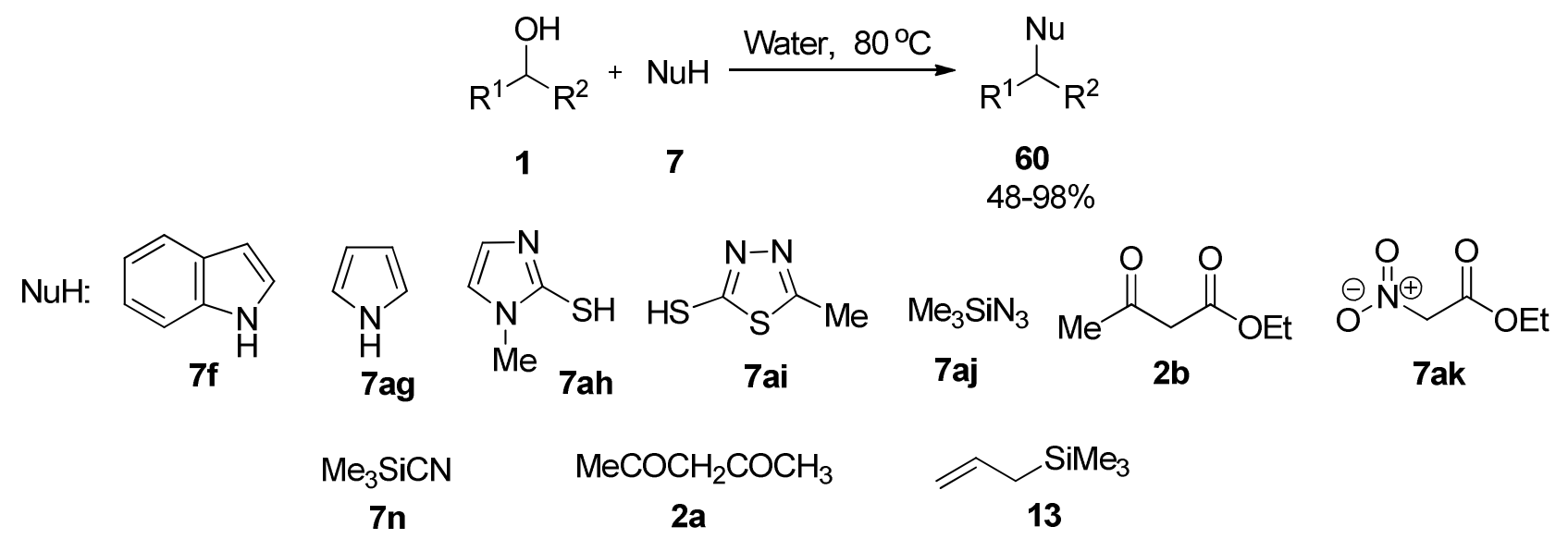

Scheme 26. Nucleophilic substitution of alcohols "on water."

Hirashita's group described the hydrothermal conditions utilizing ion-exchanged water at $220{ }^{\circ} \mathrm{C} .{ }^{193}$

Qu's group developed intramolecular nucleophilic substitution reactions of unsaturated alcohols in hot water under catalyst-free. In a mixed solvent of water and 1,1,1,3,3,3-hexafluoro-2-propanol (HFIP), polyene cyclizations using allylic alcohols provided cyclized products and in neat HFIP afforded tetracyclic products. ${ }^{194}$

\subsection{Miscellaneous}

The use of trimethylsilyl trifluoromethanesulfonate (TMSOTf) as an efficient catalyst for direct benzylation of 1,3-dicarbonyl compounds with various benzylic alcohols in $\mathrm{CH}_{3} \mathrm{NO}_{2}$ was described by Lalitha et al. ${ }^{195}$

Kaneda et al. developed an environmentally benign synthetic approach to nucleophilic substitution reactions of alcohols catalyzed by proton- and metal-exchanged montmorillonites ( $\mathrm{H}-\mathrm{and}^{\mathrm{nt}}{ }^{-}$-mont). Anilines, amides, indoles 1,3-dicarbonyl compounds and allylsilane acted as a nucleophile for the $\mathrm{H}$-mont-catalyzed substitutions of alcohols, for the formation of various $\mathrm{C}-\mathrm{N}$ and $\mathrm{C}-\mathrm{C}$ bonds. Especially, an $\mathrm{Al}^{3+}-$ mont expressed high catalytic activity for the $\alpha$-benzylation of 1,3-dicarbonyl compounds with primary alcohols (Scheme 27). ${ }^{196}$

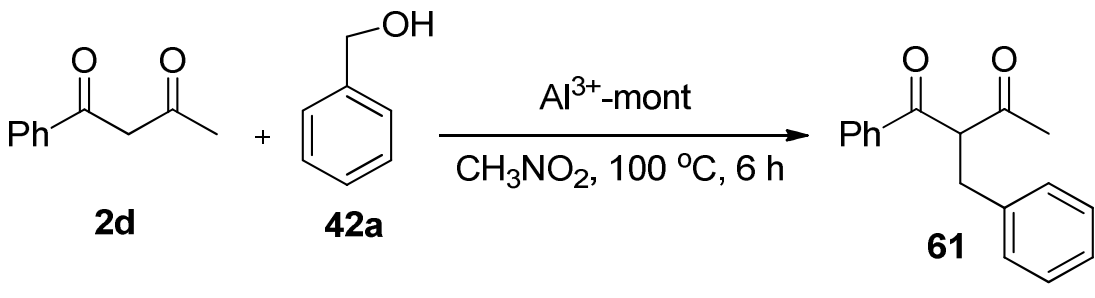

$65 \%$

Scheme 27. $\alpha$-Alkylation of benzoylacetone $\mathbf{2 d}$ with benzyl alcohol $\mathbf{4 2 a}$. 
In 2015, Takemoto and co-workers developed a combination of a halogen bond (XB) donor with trimethyl-silyl halide (TMSX) as an efficient cocatalytic system for the direct dehydroxylative coupling reaction of alcohol with different nucleophiles bearing TMS groups, such as allyltrimethylsilane and trimethylsilylcyanide, to provide the corresponding adduct ${ }^{197}$ whereas, in 2016 an effective method for cross-coupling of heteroaryl boronic acids with allylic alcohols under catalyst-free reaction conditions was reported. ${ }^{198}$

Onaka and co-workers developed a new method to transform natural montmorillonite into a solid acid catalyst employing a catalytic amount of TMSCl. The acidic montmorillonite catalyzed the azidation of benzylic and allylic alcohols with trimethylsilyazide $\left(\mathrm{TMSN}_{3}\right)^{199}$

Moreover, organohalides were found as effective catalysts for dehydrative O-alkylation of different alcohols, providing homo- and cross-etherification methods for a general preparation of the useful symmetrical and unsymmetrical aliphatic ethers. ${ }^{200}$ Hypervalent [bis(trifluoroacetoxy)iodo]benzene $\left(\mathrm{Phl}\left(\mathrm{OCOCF}_{3}\right)_{2}, \mathrm{PIFA}\right)$ catalyst has been found to function as Lewis acid for nucleophilic substitution reactions of propargylic alcohols with various of $\mathrm{C}_{-}, \mathrm{O}_{-}, \mathrm{S}-$, and $\mathrm{N}$-nucleophiles in the presence of $\mathrm{CH}_{3} \mathrm{CN}_{\text {as }}$ the solvent. $^{201}$

In 2012, Paquin and co-workers described chlorination/bromination (up to $92 \%$ yield) and iodination (in lower yields) of primary alcohols using a combination of tetraethylammonium halide (1.5 equiv.) and [Et $\mathrm{NSF}_{2}$ ] $\mathrm{BF}_{4}$ (XtalFluor-E) (1.5 equiv.), 2,6-lutidine, in $\mathrm{CH}_{2} \mathrm{Cl}_{2}$, at r.t., 12 h. ${ }^{202}$ Halogenation was limited to primary alcohols. In the case of 4-phenyl-2-butanol the halogenation was slower; as a result, fluorination became somewhat competitive (Scheme 28).

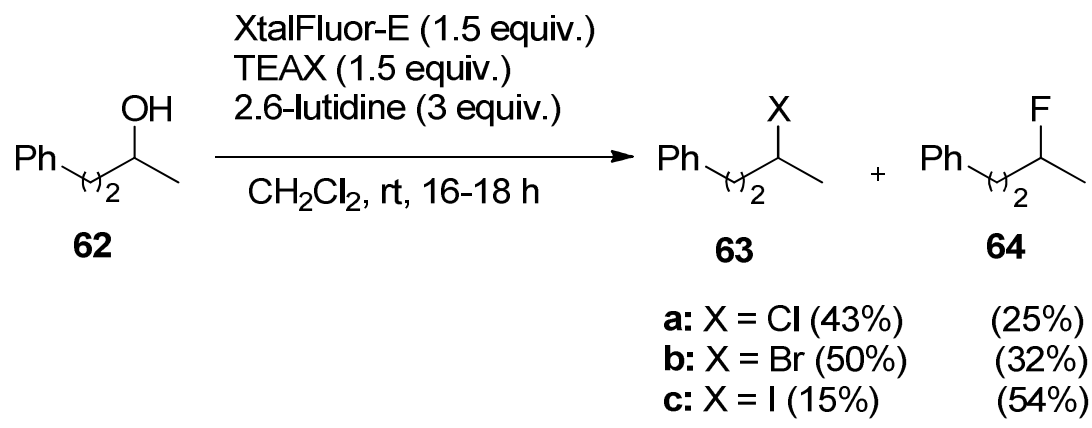

Scheme 28. Halogenation of 4-phenyl-2-butanol 62.

Lambert et al. found a convenient and efficient method for converting alcohols to alkyl chlorides in excellent yields using dichlorodiphenylcyclopropene in DCM at room temperature. ${ }^{203}$ Lautens and co-workers have shown that the combination of bromotrichloromethane $\left(\mathrm{CBrCl}_{3}\right)$ and triphenylphosphine $\left(\mathrm{PPh}_{3}\right)$, in $\mathrm{DCM}$ at r.t., for $1 \mathrm{~h}$ could convert benzyl alcohols into benzyl chlorides in excellent yields. ${ }^{204} \mathrm{Qi}$ et al. described the treatment of substituted benzyl alcohols and pyridine methanols with tosyl chloride (TsCl) and the corresponding chlorides were the main products. ${ }^{205}$ For substituted benzyl alcohols and pyridine methanols it was possible to predict whether chlorination or tosylation would occur.

Nguyen et al. developed a new method for the nucleophilic substitution of alcohols using aromatic tropylium cation activation and the chlorinated products were obtained in high yields (Scheme 29). ${ }^{206}$ 


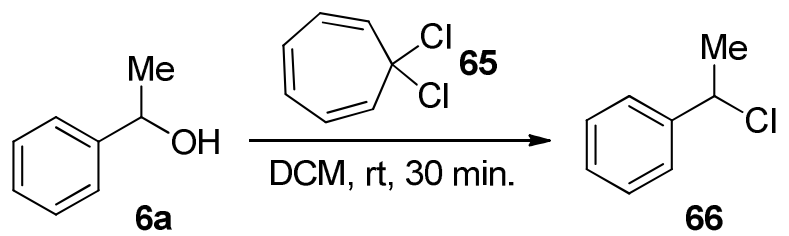

$89 \%$

Scheme 29. Chlorination of 1-phenylethanol 6a.

In 2016, an efficient method for the transformation of alcohols into the corresponding alkyl iodides and bromides using $\mathrm{KX} / \mathrm{P}_{2} \mathrm{O}_{5}(\mathrm{X}=\mathrm{Br}, \mathrm{I})$ was reported. ${ }^{207}$ Nucleophilic substitution of alcohols catalyzed by Lewis base catalyst recently has been reviewed ${ }^{208}$ and selected results are shown in Table 21 , with the acid chlorides acting as the halide source

Table 21. Nucleophilic substitution of alcohols 1 catalyzed by Lewis base catalyst

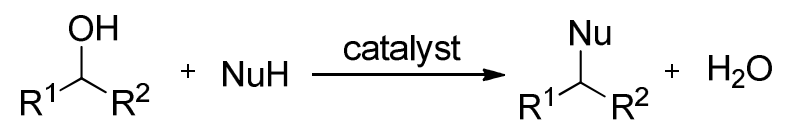

1 and $6 \quad 7 \quad 60$

\begin{tabular}{|c|c|c|c|c|c|c|}
\hline Alcohol & & $\mathrm{uH}$ & Catalyst & $\begin{array}{l}\text { Reaction } \\
\text { conditions } \\
\text { solvent/T/t }\end{array}$ & $\begin{array}{c}\text { Yield } \\
(\%)\end{array}$ & Ref. \\
\hline $6 a, R^{1}=R^{2}=P h$ & 7al & $(\mathrm{COCl})_{2}$ & $\mathrm{Ph}_{3} \mathrm{PO}$ & $\mathrm{CHCl}_{3} /$ r.t. $/ 7 \mathrm{~h}$ & 96 & 209 \\
\hline $1 \mathrm{a}, \mathrm{R}^{1}=\mathrm{Ph}, \mathrm{R}^{2}=\mathrm{Me}$ & 7al & $(\mathrm{COCl})_{2}$ & & DCM/r.t./1 h & 99 & 210 \\
\hline $1 a, R^{1}=P h, R^{2}=M e$ & 7am & $\mathrm{BzCl}$ & & MTBE & 90 & 211 \\
\hline
\end{tabular}

The most recently developed method for alcohol chlorination with silanes utilizes $\mathrm{TMSCl}$ and natural sodium montmorillonite (Na-Mont) as the catalyst in DCM. ${ }^{212}$ In the absence of the catalyst, the efficiency of the transformation was reported to be very low (8\%). The scope of this reaction is limited to secondary benzyl alcohols and strongly activated primary benzyl alcohols (Scheme 30). 


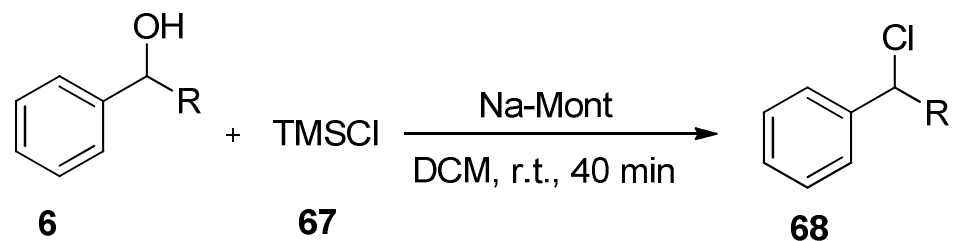

Selected substrates:

$6 b$<smiles>CC(O)c1ccccc1</smiles>

$6 a$<smiles>OC1CCCCC1</smiles>

69<smiles>OCc1ccccc1</smiles>

$42 a$

$97 \%$

$60 \%$

no reaction

no reaction<smiles>CC(O)C=Cc1ccccc1</smiles>

$20 b$<smiles>OC(/C=C/c1ccccc1)/C=C/c1ccccc1</smiles>

70

$94 \%$

polymerization

Scheme 30. Chlorination of alcohols catalyzed by Na-Mont.

Nemr and co-workers described a new method for the acetylation of cotton cellulose using acetic anhydride in the presence of NIS as a catalyst under mild reaction conditions. ${ }^{213}$

Furthermore, acetylation of sugarcane bagasse with acetic anhydride under SFRC for the production of oil sorption-active materials was performed using NBS as a catalyst. ${ }^{214}$ NBS was also used for acetylation of alcohols using acetic anhydride in DCM at room temperature. ${ }^{215}$

\section{Conclusions}

In summary, the comprehensive direct transformation of a broad range of alcohols with various sources of nucleophiles is emerging as one of the most attractive strategies from the economic and environmental point of view, producing water as a by-product of the reaction. Recent advances in this area include the activation of the hydroxyl functional group in a target molecule through the use of substoichiometric amount of Brønsted acids, Lewis acids, molecular iodine or other promoters. Still, the development of efficient, selective and environmentally benign catalytic methodologies remains an attractive research subject. We firmly believe that this review article will result in enhancing the green chemical profiles of these transformations in the future.

\section{Acknowledgements}

We are grateful to the Slovene Human Resources Development and Scholarship Fund (contract: 110119/2011) and the Slovenian Research Agency (contract: Programme P1-0134) for the financial support. 


\section{Supplementary Material}

In order to provide a broader general survey of the reactions discussed in the present paper the data are collected in the Supplementary Materials (Table S1) and organized according to the type of new bond formation.

\section{References}

1. Anastas, P. T.; Warner, J. C. Green Chemistry: Theory and Practice; Oxford University Press, 1998.

2. Ajvazi, N.; Stavber, S. Tetrahedron Lett. 2016, 57, 2430.

https://doi.org/10.1016/i.tetlet.2016.04.083

3. Ajvazi, N.; Stavber, S. Molecules 2016, 21, 1325.

https://doi.org/10.3390/molecules21101325

4. Dada, R.; Singh, G.; Pareek, A.; Kausar, S.; Yaragorla, S. Tetrahedron Lett. 2016, 57, 3739. https://doi.org/10.1016/i.tetlet.2016.07.010

5. Wagh, K. V.; Bhanage, B. M. RSC Advances 2014, 4, 22763. https://doi.org/10.1039/C4RA01324G

6. Sanz, R.; Miguel, D.; Martínez, A.; Álvarez-Gutiérrez, J. M.; Rodríguez, F. Org. Lett. 2007, 9, 2027. https://doi.org/10.1021/ol070624a

7. Wang, G.-W.; Shen, Y.-B.; Wu, X.-L. Eur. J. Org. Chem. 2008, 2008, 4999.

8. Funabiki, K.; Komeda, T.; Kubota, Y.; Matsui, M. Tetrahedron 2009, 65, 7457. https://doi.org/10.1016/i.tet.2009.07.012

9. Aoyama, T.; Yamamoto, T.; Miyota, S.; Hayakawa, M.; Takido, T.; Kodomari, M. Synlett 2014, $25,1571$. https://doi.org/10.1055/s-0033-1339026

10. Khafajeh, S.; Akhlaghinia, B.; Rezazadeh, S.; Eshghi, H. J. Chem. Sci. 2014, 126, 1903. https://doi.org/10.1007/s12039-014-0630-z

11. Shirakawa, S.; Kobayashi, S. Org. Lett. 2007, 9, 311.

https://doi.org/10.1021/ol062813j

12. Han, F.; Yang, L.; Li, Z.; Zhao, Y.; Xia, C. Adv. Synth. Catal. 2014, 356, 2506. https://doi.org/10.1002/adsc.201301150

13. Sanz, R.; Martínez, A.; Miguel, D.; Álvarez-Gutiérrez, J. M.; Rodríguez, F. Adv. Synth. Catal. 2006, 348, 1841.

https://doi.org/10.1002/adsc.200606183

14. Sanz, R.; Martínez, A.; Álvarez-Gutiérrez, J. M.; Rodríguez, F. Eur. J. Org. Chem. 2006, 1383. https://doi.org/10.1002/ejoc.200500960

15. Sanz, R.; Miguel, D.; Martínez, A.; Gohain, M.; García-García, P.; Fernández-Rodríguez, M. A.; Álvarez, E.; Rodríguez, F. Eur. J. Org. Chem. 2010, 7027. https://doi.org/10.1002/ejoc.201001055

16. McCubbin, J. A.; Nassar, C.; Krokhin, O. V. Synthesis 2011, 3152. https://doi.org/10.1055/s-0030-1260146

17. Uchuskin, M. G.; Makarov, A. S.; Butin, A. V. Chem Heterocycl Comp 2014, 50, 791. https://doi.org/10.1007/s10593-014-1534-z 
18. McCubbin, J. A.; Krokhin, O. V. Tetrahedron Letters 2010, 51, 2447.

https://doi.org/10.1016/j.tetlet.2010.02.151

19. Liu, J.; Ni, C.; Li, Y.; Zhang, L.; Wang, G.; Hu, J. Tetrahedron Lett. 2006, 47, 6753.

https://doi.org/10.1016/i.tetlet.2006.07.079

20. Chen, L.; Yin, X.-P.; Wang, C.-H.; Zhou, J. Org. Biomol. Chem., 2014, 12, 6033.

https://doi.org/10.1039/C4OB00718B

21. Gujarathi, S.; Hendrickson, H. P.; Zheng, G. Tetrahedron Lett. 2013, 54, 3550.

https://doi.org/10.1016/i.tetlet.2013.04.120

22. Yue, H.-L.; Wei, W.; Li, M.-M.; Yang, Y.-R.; Ji, J.-X. Adv. Synth. Catal. 2011, 353, 3139.

https://doi.org/10.1002/adsc.201100262

23. Wang, J.; Masui, Y.; Onaka, M. ACS Catalysis 2011, 1, 446.

https://doi.org/10.1021/cs1000812

24. Xia, F.; Zhao, Z. L.; Liu, P. N. Tetrahedron Lett. 2012, 53, 2828.

https://doi.org/10.1016/j.tetlet.2012.03.104

25. Baeza, A.; Nájera, C. Synthesis 2014, 46, 25.

https://doi.org/10.1055/s-0033-1340316

26. Sanz, R.; Miguel, D.; Martínez, A.; Álvarez-Gutiérrez, J. M.; Rodríguez, F. Org. Lett. 2007, 9, 727. https://doi.org/10.1021/ol0631298

27. Srihari, P.; Reddy, J. S. S.; Mandal, S. S.; Satyanarayana, K.; Yadav, J. S. Synthesis 2008, 1853.

28. Emer, E.; Sinisi, R.; Capdevila, M. G.; Petruzziello, D.; De Vincentiis, F.; Cozzi, P. G. Eur. J. Org. Chem. 2011, $2011,647$.

29. Kumar, R.; Van der Eycken, E. V. Chem. Soc. Rev. 2013, 42, 1121.

https://doi.org/10.1039/C2CS35397K

30. Liu, P. N.; Xia, F.; Wang, Q. W.; Ren, Y. J.; Chen, J. Q. Green Chem. 2010, 12, 1049.

https://doi.org/10.1039/b926142g

31. Liu, P. N.; Dang, L.; Wang, Q. W.; Zhao, S. L.; Xia, F.; Ren, Y. J.; Gong, X. Q.; Chen, J. Q. J. Org. Chem. 2010, 75, 5017.

https://doi.org/10.1021/jo100517k

32. Sato, Y.; Aoyama, T.; Takido, T.; Kodomari, M. Tetrahedron 2012, 68, 7077.

https://doi.org/10.1016/j.tet.2012.06.063

33. Sanz, R.; Martínez, A.; Miguel, D.; Álvarez-Gutiérrez, J. M.; Rodríguez, F. Synthesis 2007, 3252.

https://doi.org/10.1055/s-2007-983831

34. Kadam, S. T.; Lee, H.; Kim, S. S. Appl. Organomet. Chem. 2010, $24,67$.

35. Chaskar, A.; Murugan, K. Catal. Sci. Tech. 2014, 4, 1852.

https://doi.org/10.1039/c4cy00043a

36. Zhang, X.-x.; Li, L. C.; Ping, F.B.; Yao, W. -w. Chin. J. Org. Chem. 2016, 36, 1287.

https://doi.org/10.6023/cjoc201512003

37. Sayin, S.; Yilmaz, M. Tetrahedron 2016, 72, 6528.

https://doi.org/10.1016/j.tet.2016.08.066

38. Koppolu, S. R.; Naveen, N.; Balamurugan, R. J. Org. Chem. 2014, 79, 6069.

https://doi.org/10.1021/j0500759a

39. Wagh, K. V.; Bhanage, B. M. Synlett 2015, 26, 759.

https://doi.org/10.1055/s-0034-1380142 
40. Suárez, A.; Gohain, M.; Fernández-Rodríguez, M. A.; Sanz, R. J. Org. Chem. 2015, 80, 10421. https://doi.org/10.1021/acs.joc.5b02048

41. Orizu, I.; Bolshan, Y. Tetrahedron Lett. 2016, 57, 5798. https://doi.org/10.1016/i.tetlet.2016.11.044

42. Guérinot, A.; Reymond, S.; Cossy, J. Eur. J. Org. Chem. 2012, 19. https://doi.org/10.1002/ejoc.201101018

43. Sanz, R.; Martínez, A.; Guilarte, V.; Álvarez-Gutiérrez, J. M.; Rodríguez, F. Eur. J. Org. Chem. $2007,4642$. https://doi.org/10.1002/ejoc.200700562

44. Kalkhambkar, R. G.; Waters, S. N.; Laali, K. K. Tetrahedron Lett. 2011, 52, 867. https://doi.org/10.1016/j.tetlet.2010.12.028

45. Gawande, M. B.; Rathi, A. K.; Nogueira, I. D.; Varma, R. S.; Branco, P. S. Green Chem. 2013, $15,1895$. https://doi.org/10.1039/c3gc40457a

46. Zhao, X.-N.; Hu, H.-C.; Zhang, F.-J.; Zhang, Z.-H. Appl. Catal., A 2014, 482, 258.

47. Hayakawa, M.; Aoyama, T.; Kobayashi, T.; Takido, T.; Kodomari, M. Synlett 2014, 25, 2365. https://doi.org/10.1055/s-0034-1378580

48. Khaksar, S.; Fattahi, E.; Fattahi, E. Tetrahedron Lett. 2011, 52, 5943. https://doi.org/10.1016/i.tetlet.2011.08.121

49. Jiang, S.; Wang, Z.; Jiang, Z.; Li, J.; Zhou, S.; Pu, L. Lett. Org. Chem. 2012, 9, 24. https://doi.org/10.2174/157017812799304006

50. Jiang, D.; He, T.; Ma, L.; Wang, Z. RSC Advances 2014, 4, 64936. https://doi.org/10.1039/C4RA10784E

51. Yu, J.-L.; Wang, H.; Zou, K.-F.; Zhang, J.-R.; Gao, X.; Zhang, D.-W.; Li, Z.-T. Tetrahedron 2013, 69, 310. https://doi.org/10.1016/i.tet.2012.10.032

52. Mallesha, N.; Prahlada Rao, S.; Suhas, R.; Channe Gowda, D. Tetrahedron Lett. 2012, 53, 641. https://doi.org/10.1016/i.tetlet.2011.11.108

53. Altimari, J. M.; Delaney, J. P.; Servinis, L.; Squire, J. S.; Thornton, M. T.; Khosa, S. K.; Long, B. M.; Johnstone, M. D.; Fleming, C. L.; Pfeffer, F. M.; Hickey, S. M.; Wride, M. P.; Ashton, T. D.; Fox, B. L.; Byrne, N.; Henderson, L. C. Tetrahedron Lett. 2012, 53, 2035. https://doi.org/10.1016/i.tetlet.2012.02.011

54. Aoyama, T.; Furukawa, T.; Hayakawa, M.; Takido, T.; Kodomari, M. Synlett 2015, 26, 1875. https://doi.org/10.1055/s-0034-1380863

55. Bunrit, A.; Dahlstrand, C.; Olsson, S. K.; Srifa, P.; Huang, G.; Orthaber, A.; Sjöberg, P. J. R.; Biswas, S.; Himo, F.; Samec, J. S. M. J. Am. Chem. Soc. 2015, 137, 4646.

https://doi.org/10.1021/jacs.5b02013

56. Bunrit, A.; Dahlstrand, C.; Srifa, P.; Olsson, S. K.; Huang, G.; Biswas, S.; Himo, F.; Samec, J. S. M. Synlett 2016, 27, 173.

57. Noji, M.; Ohno, T.; Fuji, K.; Futaba, N.; Tajima, H.; Ishii, K. J. Org. Chem. 2003, 68, 9340. https://doi.org/10.1021/jo034255h

58. Yasuda, M.; Somyo, T.; Baba, A. Angew. Chem. Int. Ed. 2006, 45, 793. https://doi.org/10.1002/anie.200503263

59. Kothandaraman, P.; Rao, W.; Zhang, X.; Chan, P. W. H. Tetrahedron 2009, 65, 1833. https://doi.org/10.1016/j.tet.2008.11.102

60. Saito, T.; Nishimoto, Y.; Yasuda, M.; Baba, A. J. Org. Chem. 2007, 72, 8588. 
https://doi.org/10.1021/jo7015289

61. Noji, M.; Konno, Y.; Ishii, K. J. Org. Chem. 2007, 72, 5161.

https://doi.org/10.1021/jo0705216

62. Babu, S. A.; Yasuda, M.; Tsukahara, Y.; Yamauchi, T.; Wada, Y.; Baba, A. Synthesis 2008, 1717. https://doi.org/10.1055/s-2008-1067020

63. Zhang, X.; Rao, W.; Sally; Chan, P. W. H. Org. Biomol. Chem., 2009, 7, 4186. https://doi.org/10.1039/b908447a

64. Thirupathi, P.; Kim, S. S. Tetrahedron 2010, 66, 2995. https://doi.org/10.1016/i.tet.2010.02.063

65. Ben Othman, R.; Affani, R.; Tranchant, M.-J.; Antoniotti, S.; Dalla, V.; Duñach, E. Angew. Chem. 2010, 122, 788.

https://doi.org/10.1002/ange.200906036

66. Kischel, J.; Mertins, K.; Michalik, D.; Zapf, A.; Beller, M. Adv. Synth. Catal. 2007, 349, 865. https://doi.org/10.1002/adsc.200600497

67. Aridoss, G.; Laali, K. K. Tetrahedron Lett. 2011, 52, 6859.

https://doi.org/10.1016/i.tetlet.2011.10.021

68. Rueping, M.; Nachtsheim, B. J.; Kuenkel, A. Org. Lett. 2007, 9, 825. https://doi.org/10.1021/ol063048b

69. Yadav, J. S.; Bhunia, D. C.; Vamshi Krishna, K.; Srihari, P. Tetrahedron Lett. 2007, 48, 8306. https://doi.org/10.1016/i.tetlet.2007.09.140

70. Jana, U.; Maiti, S.; Biswas, S. Tetrahedron Lett. 2007, 48, 7160. https://doi.org/10.1016/j.tetlet.2007.07.208

71. Jana, U.; Biswas, S.; Maiti, S. Eur. J. Org. Chem. 2008, 5798. https://doi.org/10.1002/ejoc.200800713

72. Jana, U.; Maiti, S.; Biswas, S. Tetrahedron Lett. 2008, 49, 858. https://doi.org/10.1016/i.tetlet.2007.11.176

73. Narahashi, H.; Shimizu, I.; Yamamoto, A. J. Organomet. Chem. 2008, 693, 283. https://doi.org/10.1016/j.jorganchem.2007.10.051

74. Lee, D.-H.; Kwon, K.-H.; Yi, C. S. Science 2011, 333, 1613. https://doi.org/10.1126/science.1208839

75. Yasuda, M.; Saito, T.; Ueba, M.; Baba, A. Angew. Chem. Int. Ed. 2004, 43, 1414. https://doi.org/10.1002/anie.200353121

76. Yadav, J. S.; Subba Reddy, B. V.; Srinivasa Rao, T.; Raghavendra Rao, K. V. Tetrahedron Lett. 2008, $49,614$. https://doi.org/10.1016/i.tetlet.2007.11.143

77. Hassner, A.; Bandi, C. R. Synlett 2013, 24, 1275. https://doi.org/10.1055/s-0033-1338746

78. Saito, T.; Nishimoto, Y.; Yasuda, M.; Baba, A. J. Org. Chem. 2006, 71, 8516. https://doi.org/10.1021/jo061512k

79. Zhan, Z.-p.; Yu, J.-I.; Liu, H.-j.; Cui, Y.-y.; Yang, R.-f.; Yang, W.-z.; Li, J.-p. J. Org. Chem. 2006, 71, 8298. https://doi.org/10.1021/jo061234p

80. Zhan, Z.-p.; Yang, W.-z.; Yang, R.-f.; Yu, J.-I.; Li, J.-p.; Liu, H.-j. Chem. Commun. 2006, 3352. https://doi.org/10.1039/b606470a

81. Luzung, M. R.; Toste, F. D. J. Am. Chem. Soc. 2003, 125, 15760. 
https://doi.org/10.1021/ja039124c

82. Georgy, M.; Boucard, V.; Campagne, J.-M. J. Am. Chem. Soc. 2005, 127, 14180.

https://doi.org/10.1021/ja0534147

83. Narayana Kumar, G. G. K. S.; Laali, K. K. Org. Biomol. Chem., 2012, 10, 7347.

https://doi.org/10.1039/c2ob26046h

84. Das, D.; Pratihar, S.; Roy, U. K.; Mal, D.; Roy, S. Org. Biomol. Chem., 2012, 10, 4537.

https://doi.org/10.1039/c2ob25275a

85. Niggemann, M.; Meel, M. J. Angew. Chem. Int. Ed. 2010, 49, 3684.

https://doi.org/10.1002/anie.200907227

86. Siddiki, S. M. A. H.; Kon, K.; Shimizu, K.-i. Chem. Eur. J. 2013, 19, 14416.

https://doi.org/10.1002/chem.201302464

87. Usui, I.; Schmidt, S.; Keller, M.; Breit, B. Org. Lett. 2008, 10, 1207.

https://doi.org/10.1021/ol800073v

88. van Rijn, J. A.; Guijt, M. C.; de Vries, D.; Bouwman, E.; Drent, E. Appl. Organomet. Chem. 2011, $25,212$. https://doi.org/10.1002/aoc.1744

89. van Rijn, J. A.; van Stapele, E.; Bouwman, E.; Drent, E. J. Catal. 2010, 272, 220.

https://doi.org/10.1016/i.jcat.2010.04.002

90. Yang, S.-C.; Tsai, Y.-C.; Shue, Y.-J. Organometallics 2001, 20, 5326.

https://doi.org/10.1021/om0107136

91. Utsunomiya, M.; Miyamoto, Y.; Ipposhi, J.; Ohshima, T.; Mashima, K. Org. Lett. 2007, 9, 3371. https://doi.org/10.1021/ol071365s

92. Sundararaju, B.; Achard, M.; Bruneau, C. Chem. Soc. Rev. 2012, 41, 4467.

https://doi.org/10.1039/c2cs35024f

93. Nishibayashi, Y.; Yoshikawa, M.; Inada, Y.; Hidai, M.; Uemura, S. J. Am. Chem. Soc. 2002, 124, 11846. https://doi.org/10.1021/ja027023t

94. Nishibayashi, Y.; Inada, Y.; Yoshikawa, M.; Hidai, M.; Uemura, S. Angew. Chem. Int. Ed. 2003, 42, 1495. https://doi.org/10.1002/anie.200250532

95. Kuninobu, Y.; Ueda, H.; Takai, K. Chem.Lett. 2008, 37, 878.

https://doi.org/10.1246/cl.2008.878

96. Kennedy-Smith, J. J.; Young, L. A.; Toste, F. D. Org. Lett. 2004, 6, 1325.

https://doi.org/10.1021/ol049649p

97. Dhiman, S.; Ramasastry, S. S. V. Org. Biomol. Chem., 2013, 11, 4299.

https://doi.org/10.1039/c3ob40814k

98. Inada, Y.; Nishibayashi, Y.; Hidai, M.; Uemura, S. J. Am. Chem. Soc. 2002, 124, 15172.

https://doi.org/10.1021/ja027754t

99. Gohain, M.; Marais, C.; Bezuidenhoudt, B. C. B. Tetrahedron Lett. 2012, 53, 4704. https://doi.org/10.1016/i.tetlet.2012.06.095

100. Ren, K.; Li, P.; Wang, L.; Zhang, X. Tetrahedron 2011, 67, 2753.

https://doi.org/10.1016/i.tet.2011.02.050

101. Chen, G.-Q.; Xu, Z.-J.; Chan, S. L.-F.; Zhou, C.-Y.; Che, C.-M. Synlett 2011, 22, 2713.

102. Theerthagiri, P.; Lalitha, A. Tetrahedron Lett. 2012, 53, 5535.

https://doi.org/10.1016/j.tetlet.2012.08.021

103. Shukla, P.; Choudhary, M. K.; Nayak, S. K. Synlett 2011, 22, 1585. 
104. Rueping, M.; Nachtsheim, B. J.; leawsuwan, W. Adv. Synth. Catal. 2006, 348, 1033. https://doi.org/10.1002/adsc.200606068

105. Zhang, X.; Teo, W. T.; Chan, P. W. H. Org. Lett. 2009, 11, 4990. https://doi.org/10.1021/ol901981s

106. Khafajeh, S.; Akhlaghinia, B.; Rezazadeh, S.; Eshghi, H. J. Chem. Sci. 2014, 126, 1903.

107. Morita, N.; Miyamoto, M.; Yoda, A.; Yamamoto, M.; Ban, S.; Hashimoto, Y.; Tamura, O. Tetrahedron Lett. 2016, 57, 4460 . https://doi.org/10.1016/j.tetlet.2016.08.045

108. Abidi, A.; Oueslati, Y.; Rezgui, F. Beilstein J. Org. Chem. 2016, 12, 2402. https://doi.org/10.3762/bjoc.12.234

109. Cao, X.; Zhang, Y. Green Chem. 2016, 18, 2638. https://doi.org/10.1039/C6GC00163G

110. Trillo, P.; Pastor, I. M. Adv. Synth. Catal. 2016, 358, 2929. https://doi.org/10.1002/adsc.201600315

111. Webster, S.; Schaefer, L.; Barker, G.; Lee, A.-L. Synlett 2015, 26, 2673. https://doi.org/10.1055/s-0035-1560648

112. Dryzhakov, M.; Richmond, E.; Moran, J. Synthesis 2016, 48, 935. https://doi.org/10.1055/s-0035-1560396

113. Maity, A. K.; Chatterjee, P. N.; Roy, S. Tetrahedron 2013, 69, 942. https://doi.org/10.1016/j.tet.2012.10.086

114. Teranishi, S.; Kurahashi, T.; Matsubara, S. Synlett 2013, 24, 2148. https://doi.org/10.1055/s-0033-1339640

115. Callens, E.; Burton, A. J.; Barrett, A. G. M. Tetrahedron Lett. 2006, 47, 8699. https://doi.org/10.1016/j.tetlet.2006.10.023

116. Ibrahim, N.; Hashmi, A. S. K.; Rominger, F. Adv. Synth. Catal. 2011, 353, 461. https://doi.org/10.1002/adsc.201000779

117. Yaragorla, S.; Singh, G.; Lal Saini, P.; Reddy, M. K. Tetrahedron Lett. 2014, 55, 4657. https://doi.org/10.1016/j.tetlet.2014.06.068

118. Zhu, A.; Li, L.; Wang, J.; Zhuo, K. Green Chem. 2011, 13, 1244. https://doi.org/10.1039/c0gc00763c

119. Agrawal, S.; Lenormand, M.; Martín-Matute, B. Org. Lett. 2012, 14, 1456. https://doi.org/10.1021/ol3001969

120. Liu, Y.-L.; Liu, L.; Wang, D.; Chen, Y.-J. Tetrahedron 2009, 65, 3473. https://doi.org/10.1016/i.tet.2009.02.048

121. Wu, C.; Liu, Y.; Zeng, H.; Liu, L.; Wang, D.; Chen, Y. Org. Biomol. Chem. 2011, 9, 253. https://doi.org/10.1039/COOB00604A

122. Ohshima, T.; Ipposhi, J.; Nakahara, Y.; Shibuya, R.; Mashima, K. Adv. Synth. Catal. 2012, 354, 2447. https://doi.org/10.1002/adsc.201200536

123. Cui, X.; Dai, X.; Deng, Y.; Shi, F. Chem. Eur. J. 2013, 19, 3665. https://doi.org/10.1002/chem.201203417

124. Bala, M.; Verma, P. K.; Sharma, U.; Kumar, N.; Singh, B. Green Chem. 2013, 15, 1687. https://doi.org/10.1039/c3gc40137e 
125. Wang, D.; Guo, X.-Q.; Wang, C.-X.; Wang, Y.-N.; Zhong, R.; Zhu, X.-H.; Cai, L.-H.; Gao, Z.-W.; Hou, X.-F. Adv. Synth. Catal. 2013, 355, 1117.

https://doi.org/10.1002/adsc.201200732

126. Haubenreisser, S.; Niggemann, M. Adv. Synth. Catal. 2011, 353, 469. https://doi.org/10.1002/adsc.201000768

127. Fujita, K.-i.; Enoki, Y.; Yamaguchi, R. Tetrahedron 2008, 64, 1943. https://doi.org/10.1016/i.tet.2007.11.083

128. Watson, A. J. A.; Maxwell, A. C.; Williams, J. M. J. J. Org. Chem. 2011, 76, 2328. https://doi.org/10.1021/jo102521a

129. Zhang, Y.; Qi, X.; Cui, X.; Shi, F.; Deng, Y. Tetrahedron Lett. 2011, 52, 1334. https://doi.org/10.1016/i.tetlet.2011.01.059

130. Kawahara, R.; Fujita, K.-i.; Yamaguchi, R. Adv. Synth. Catal. 2011, 353, 1161. https://doi.org/10.1002/adsc.201000962

131. Zhao, Y.; Foo, S. W.; Saito, S. Angew. Chem. Int. Ed. 2011, 50, 3006. https://doi.org/10.1002/anie.201006660

132. Blank, B.; Madalska, M.; Kempe, R. Adv. Synth. Catal. 2008, 350, 749. https://doi.org/10.1002/adsc.200700596

133. Cano, R.; Ramón, D. J.; Yus, M. J. Org. Chem. 2011, 76, 5547. https://doi.org/10.1021/jo200559h

134. Bähn, S.; Imm, S.; Neubert, L.; Zhang, M.; Neumann, H.; Beller, M. ChemCatChem 2011, 3, 1853. https://doi.org/10.1002/cctc.201100255

135. Wang, M.; Xie, Y.; Li, J.; Huang, H. Synlett 2014, 25, 2781. https://doi.org/10.1055/s-0034-1379249

136. Pan, J.; Li, J.-q.; Huang, R.-f.; Zhang, X.-h.; Shen, H.; Xiong, Y.; Zhu, X.-m. Synlett 2015, 26, 1101. https://doi.org/10.1055/s-0034-1378708

137. Chen, S.-j.; Lu, G.-p.; Cai, C. Synthesis 2015, 47, 976. https://doi.org/10.1055/s-0034-1380110

138. Hikawa, H.; Ijichi, Y.; Kikkawa, S.; Azumaya, I. Eur. J. Org. Chem. 2017, 465. https://doi.org/10.1002/ejoc.201601501

139. Boyer, B.; Keramane, E.-M.; Roque, J.-P.; Pavia, A. A. Tetrahedron Lett. 2000, 41, 2891. https://doi.org/10.1016/S0040-4039(00)00304-X

140. Kadota, I.; Lutete, L. M.; Shibuya, A.; Yamamoto, Y. Tetrahedron Lett. 2001, 42, 6207. https://doi.org/10.1016/S0040-4039(01)01207-2

141. Zhang, W.; Haight, A. R.; Hsu, M. C. Tetrahedron Lett. 2002, 43, 6575. https://doi.org/10.1016/S0040-4039(02)01436-3

142. Miller, Kimberly J.; Abu-Omar, Mahdi M. Eur. J. Org. Chem. 2003, 1294. https://doi.org/10.1002/ejoc.200390185

143. Kayaki, Y.; Koda, T.; Ikariya, T. J. Org. Chem. 2004, 69, 2595. https://doi.org/10.1021/jo030370g

144. Bikard, Y.; Weibel, J.-M.; Sirlin, C.; Dupuis, L.; Loeffler, J.-P.; Pale, P. Tetrahedron Lett. 2007, $48,8895$. https://doi.org/10.1016/i.tetlet.2007.10.045

145. Bikard, Y.; Mezaache, R.; Weibel, J.-M.; Benkouider, A.; Sirlin, C.; Pale, P. Tetrahedron 2008, 64, 10224. https://doi.org/10.1016/i.tet.2008.08.026 
146. Cuenca, A. B.; Mancha, G.; Asensio, G.; Medio-Simón, M. Chem. Eur. J. 2008, 14, 1518. https://doi.org/10.1002/chem.200701134

147. Kalviri, H. A.; Petten, C. F.; Kerton, F. M. Chem. Commun. 2009, 5171. https://doi.org/10.1039/b909866f

148. Corma, A.; Navas, J.; Ródenas, T.; Sabater, M. J. Chem. Eur. J. 2013, 19, 17464. https://doi.org/10.1002/chem.201302226

149. Sherry, B. D.; Radosevich, A. T.; Toste, F. D. J. Am. Chem. Soc. 2003, 125, 6076. https://doi.org/10.1021/ja0343050

150. Li, J.; Zhang, X.; Shen, H.; Liu, Q.; Pan, J.; Hu, W.; Xiong, Y.; Chen, C. Adv. Synth. Catal. 2015, $357,3115$. https://doi.org/10.1002/adsc.201500663

151. Moghadam, B. N.; Akhlaghinia, B.; Rezazadeh, S. Res. Chem. Intermed. 2016, 42, 1487. https://doi.org/10.1007/s11164-015-2098-y

152. Hikawa, H.; Machino, Y.; Toyomoto, M.; Kikkawa, S.; Azumaya, I. Org. Biomol. Chem., 2016, 14, 7038. https://doi.org/10.1039/C60B01140C

153. Azizi, N.; Saidi, M. R. Organometallics 2003, 23, 1457.

https://doi.org/10.1021/om0341505

154. Narsaiah, A. V. J. Organomet. Chem. 2007, 692, 3614. https://doi.org/10.1016/i.jorganchem.2007.05.002

155. Chen, G.; Wang, Z.; Wu, J.; Ding, K. Org. Lett. 2008, 10, 4573. https://doi.org/10.1021/ol801812a

156. Yasuda, M.; Yamasaki, S.; Onishi, Y.; Baba, A. J. Am. Chem. Soc. 2004, 126, 7186. https://doi.org/10.1021/ja048688t

157. Yasuda, M.; Shimizu, K.; Yamasaki, S.; Baba, A. Org. Biomol. Chem., 2008, 6, 2790. https://doi.org/10.1039/b804589e

158. Bauer, I.; Knölker, H.-J. Chem. Rev. 2015, 115, 3170. https://doi.org/10.1021/cr500425u

159. Namboodiri, V. V.; Varma, R. S. Tetrahedron Lett. 2002, 43, 4593. https://doi.org/10.1016/S0040-4039(02)00890-0

160. Reddy, M. A.; Reddy, P. S.; Sreedhar, B. Adv. Synth. Catal. 2010, 352, 1861. https://doi.org/10.1002/adsc.200900905

161. Han, J.; Cui, Z.; Wang, J.; Liu, Z. Synth. Commun. 2010, 40, 2042. https://doi.org/10.1080/00397910903219393

162. Xiang, S.-K.; Zhang, L.-H.; Jiao, N. Chem. Commun. 2009, 6487. https://doi.org/10.1039/b911905a

163. Zhang, L.; Fang, G.; Kumar, R. K.; Bi, X. Synthesis 2015, 47, 2317. https://doi.org/10.1055/s-0034-1378852

164. Georgy, M.; Boucard, V.; Debleds, O.; Zotto, C. D.; Campagne, J.-M. Tetrahedron 2009, 65, 1758. https://doi.org/10.1016/i.tet.2008.12.051

165. Pennell, M. N.; Turner, P. G.; Sheppard, T. D. Chem. Eur. J. 2012, 18, 4748. https://doi.org/10.1002/chem.201102830

166. Hui, H.-h.; Zhao, Q.; Yang, M.-y.; She, D.-b.; Chen, M.; Huang, G.-s. Synthesis 2008, 191.

167. Vinson, A. R. S.; Davis, V. K.; Arunasalam, A.; Jesse, K. A.; Hamilton, R. E.; Shattuck, M. A.; Hu, A. C.; lafe, R. G.; Wenzel, A. G. Synlett 2015, 26, 765. 
https://doi.org/10.1055/s-0034-1380128

168. Queensen, M. J.; Rabus, J. M.; Bauer, E. B. J. Mol. Catal. A: Chem. 2015, 407, 221.

https://doi.org/10.1016/j.molcata.2015.06.009

169. Liu, Z.-Q.; Zhang, Y.; Zhao, L.; Li, Z.; Wang, J.; Li, H.; Wu, L.-M. Org. Lett. 2011, 13, 2208.

https://doi.org/10.1021/ol200372y

170. Liu, P. N.; Zhou, Z. Y.; Lau, C. P. Chem. Eur. J. 2007, 13, 8610.

https://doi.org/10.1002/chem.200700705

171. Jereb, M.; Vražič, D.; Zupan, M. Tetrahedron 2011, 67, 1355.

https://doi.org/10.1016/j.tet.2010.11.086

172. Li, Z.; Duan, Z.; Wang, H.; Tian, R.; Zhu, Q.; Wu, Y. Synlett 2008, 2535.

173. Srihari, P.; Bhunia, D. C.; Sreedhar, P.; Yadav, J. S. Synlett 2008, 1045.

https://doi.org/10.1055/s-2008-1072652

174. Sun, G.; Wang, Z. Tetrahedron Lett. 2008, 49, 4929.

https://doi.org/10.1016/i.tetlet.2008.05.146

175. Lin, X.; Wang, J.; Xu, F.; Wang, Y. J. Chem. Res. 2009, 33, 638.

https://doi.org/10.3184/030823409X12526892025900

176. Theerthagiri, P.; Lalitha, A.; Arunachalam, P. N. Tetrahedron Lett. 2010, 51, 2813.

https://doi.org/10.1016/i.tetlet.2010.03.057

177. Lin, X.; Dai, X.; Mao, Z.; Wang, Y. Tetrahedron 2009, 65, 9233.

https://doi.org/10.1016/i.tet.2009.09.007

178. Yadav, J. S.; Reddy, B. V. S.; Reddy, A. S.; Eeshwaraiah, B. Chem. Lett. 2007, 36, 1500.

https://doi.org/10.1246/cl.2007.1500

179. Zhang, X.; Rao, W.; Chan, P. W. H. Synlett 2008, 2204.

180. Rao, W.; Tay, A. H. L.; Goh, P. J.; Choy, J. M. L.; Ke, J. K.; Chan, P. W. H. Tetrahedron Lett. 2008, 49, 122. https://doi.org/10.1016/j.tetlet.2007.11.005

181. Rao, W.; Tay, A. H. L.; Goh, P. J.; Choy, J. M. L.; Ke, J. K.; Chan, P. W. H. Tetrahedron Lett. 2008, 49, 5115. https://doi.org/10.1016/i.tetlet.2007.11.214

182. Wu, W.; Rao, W.; Er, Y. Q.; Loh, J. K.; Poh, C. Y.; Chan, P. W. H. Tetrahedron Lett. 2008, 49, 2620. https://doi.org/10.1016/i.tetlet.2008.02.079

183. Wu, W.; Rao, W.; Er, Y. Q.; Loh, J. K.; Poh, C. Y.; Hong Chan, P. W. Tetrahedron Lett. 2008, 49, 4981. https://doi.org/10.1016/i.tetlet.2008.02.176

184. Shafiq, Z.; Qiao, Z.; Liu, L.; Zheng, Q.-Y.; Wang, D.; Chen, Y.-J. Synlett 2009, 2965.

185. Srihari, P.; Bhunia, D. C.; Sreedhar, P.; Mandal, S. S.; Reddy, J. S. S.; Yadav, J. S. Tetrahedron Lett. 2007, 48, 8120.

https://doi.org/10.1016/i.tetlet.2007.09.123

186. Yadav, J. S.; Reddy, B. V. S.; Thrimurtulu, N.; Reddy, N. M.; Prasad, A. R. Tetrahedron Lett. 2008, 49, 2031. https://doi.org/10.1016/i.tetlet.2008.01.017

187. Stavber, G.; Zupan, M.; Stavber, S. Tetrahedron Lett. 2006, 47, 8463.

https://doi.org/10.1016/j.tetlet.2006.09.154

188. Liu, Z.; Wang, D.; Chen, Y. Lett. Org. Chem. 2011, 8, 73.

https://doi.org/10.2174/157017811794557787

189. Jereb, M. Tetrahedron 2012, 68, 3861.

https://doi.org/10.1016/i.tet.2012.03.040 
190. Bhunia, N.; Das, B. Synthesis 2013, 45, 1045.

https://doi.org/10.1055/s-0032-1318485

191. Trillo, P.; Baeza, A.; Nájera, C. J. Org. Chem. 2012, 77, 7344.

https://doi.org/10.1021/jo301049w

192. Cozzi, P. G.; Zoli, L. Angew. Chem. Int. Ed. 2008, 47, 4162.

https://doi.org/10.1002/anie.200800622

193. Hirashita, T.; Kuwahara, S.; Okochi, S.; Tsuji, M.; Araki, S. Tetrahedron Lett. 2010, 51, 1847. https://doi.org/10.1016/i.tetlet.2010.01.112

194. Zhang, F.-Z.; Tian, Y.; Li, G.-X.; Qu, J. J. Org. Chem. 2015, 80, 1107.

https://doi.org/10.1021/jo502636d

195. Theerthagiri, P.; Lalitha, A. Tetrahedron Lett. 2010, 51, 5454.

https://doi.org/10.1016/i.tetlet.2010.08.019

196. Motokura, K.; Nakagiri, N.; Mizugaki, T.; Ebitani, K.; Kaneda, K. J. Org. Chem. 2007, 72, 6006. https://doi.org/10.1021/jo070416w

197. Saito, M.; Tsuji, N.; Kobayashi, Y.; Takemoto, Y. Org. Lett. 2015, 17, 3000.

https://doi.org/10.1021/acs.orglett.5b01290

198. Li, X.-D.; Xie, L.-J.; Kong, D.-L.; Liu, L.; Cheng, L. Tetrahedron 2016, 72, 1873.

https://doi.org/10.1016/i.tet.2016.02.047

199. Tandiary, M. A.; Masui, Y.; Onaka, M. RSC Advances 2015, 5, 15736.

https://doi.org/10.1039/C4RA13238F

200. Xu, Q.; Xie, H.; Chen, P.; Yu, L.; Chen, J.; Hu, X. Green Chem. 2015, 17, 2774.

https://doi.org/10.1039/C5GC00284B

201. Weng, S.-S.; Hsieh, K.-Y.; Zeng, Z.-J. Tetrahedron 2015, 71, 2549.

https://doi.org/10.1016/j.tet.2015.03.013

202. Pouliot, M.-F.; Mahé, O.; Hamel, J.-D.; Desroches, J.; Paquin, J.-F. Org. Lett. 2012, 14, 5428.

https://doi.org/10.1021/ol302496q

203. Kelly, B. D.; Lambert, T. H. J. Am. Chem. Soc. 2009, 131, 13930.

https://doi.org/10.1021/ja906520p

204. Newman, S. G.; Bryan, C. S.; Perez, D.; Lautens, M. Synthesis 2011, 342.

205. Ding, R.; He, Y.; Wang, X.; Xu, J.; Chen, Y.; Feng, M.; Qi, C. Molecules 2011, 16, 5665.

https://doi.org/10.3390/molecules16075665

206. Nguyen, T. V.; Bekensir, A. Org. Lett. 2014, 16, 1720.

https://doi.org/10.1021/ol5003972

207. Khazdooz, L.; Zarei, A.; Aghaei, H.; Azizi, G.; Gheisari, M. M. Tetrahedron Lett. 2016, 57, 168. https://doi.org/10.1016/i.tetlet.2015.11.078

208. Huy, P. H.; Hauch, T.; Filbrich, I. Synlett 2016, 27, 2631.

https://doi.org/10.1055/s-0036-1588633

209. Denton, R. M.; An, J.; Adeniran, B.; Blake, A. J.; Lewis, W.; Poulton, A. M. J. Org. Chem. 2011, 76, 6749. https://doi.org/10.1021/jo201085r

210. Vanos, C. M.; Lambert, T. H. Angew. Chem. Int. Ed. 2011, 50, 12222.

https://doi.org/10.1002/anie.201104638

211. Huy, P. H.; Motsch, S.; Kappler, S. M. Angew. Chem. Int. Ed. 2016, 55, 10145.

https://doi.org/10.1002/anie.201604921 
212. Tandiary, M. A.; Masui, Y.; Onaka, M. Synlett 2014, 25, 2639. https://doi.org/10.1055/s-0034-1379226

213. El Nemr, A.; Ragab, S.; El Sikaily, A.; Khaled, A. Carbohydr. Polym. 2015, 130, 41. https://doi.org/10.1016/i.carbpol.2015.04.065

214. Sun, X. F.; Sun, R. C.; Sun, J. X. Bioresour. Technol. 2004, 95, 343. https://doi.org/10.1016/j.biortech.2004.02.025

215. Karimi, B.; Seradj, H. Synlett 2001, 519. https://doi.org/10.1055/s-2001-12321 